\title{
Role of chemokines in hepatocellular carcinoma (Review)
}

\author{
DONGDONG XUE $^{1 *}$, YA ZHENG $^{2 *}$, JUNYE WEN $^{1}$, JINGZHAO HAN $^{1}$, \\ HONGFANG TUO ${ }^{1}$, YIFAN LIU ${ }^{1}$ and YANHUI PENG ${ }^{1}$ \\ ${ }^{1}$ Department of Hepatobiliary Surgery, Hebei General Hospital, Shijiazhuang, Hebei 050051; ${ }^{2}$ Medical Center Laboratory, \\ Tongji Hospital Affiliated to Tongji University School of Medicine, Shanghai 200065, P.R. China
}

Received September 5, 2020; Accepted December 4, 2020

DOI: $10.3892 / o r .2020 .7906$

\begin{abstract}
Hepatocellular carcinoma (HCC) is a prevalent malignant tumor worldwide, with an unsatisfactory prognosis, although treatments are improving. One of the main challenges for the treatment of HCC is the prevention or management of recurrence and metastasis of HCC. It has been found that chemokines and their receptors serve a pivotal role in HCC progression. In the present review, the literature on the multifactorial roles of exosomes in HCC from PubMed, Cochrane library and Embase were obtained, with a specific focus on the functions and mechanisms of chemokines in HCC. To date, $>50$ chemokines have been found, which can be divided into four families: CXC, CX3C, $\mathrm{CC}$ and XC, according to the different positions of the conserved $\mathrm{N}$-terminal cysteine residues. Chemokines are involved in the inflammatory response, tumor immune response, proliferation, invasion and metastasis via modulation of various signaling pathways. Thus, chemokines and their receptors directly or indirectly shape the tumor cell microenvironment, and regulate the biological behavior of the tumor. In addition, the potential application of chemokines in chemotaxis of exosomes as drug vehicles is discussed. Exosomes containing chemokines or expressing receptors for chemokines may improve chemotaxis to HCC and may thus be exploited for targeted drug delivery.
\end{abstract}

\section{Contents}

1. Introduction

2. HCC-associated chemokines

3. Chemokines, exosomes and HCC

4. Conclusions and future prospects

Correspondence to: Professor Yanhui Peng, Department of Hepatobiliary Surgery, Hebei General Hospital, 348 West He-Ping Road, Shijiazhuang, Hebei 050051, P.R. China

E-mail: yhpeng@hebmu.edu.cn

${ }^{*}$ Contributed equally

Key words: hepatocellular carcinoma, metastasis, chemokine, exosomes, targeted treatment

\section{Introduction}

Hepatocellular carcinoma (HCC) is the sixth most common type of cancer worldwide and the third leading cause of cancer-associated death (1). Most patients cannot undergo radical surgery due to the presence of intrahepatic or distant organ metastases, and at present, the primary treatment methods for HCC include surgery, local ablation therapy and radiation intervention (2). These methods allow for effective treatment and management of patients with HCC during the early stages, with 5-year survival rates as high as $70 \%$ (3). Despite the continuous development of traditional treatment methods, the issue of recurrence and metastasis of HCC, causing adverse effects to the survival and prognosis of patients, remains a notable challenge. HCC is a heterogeneous and chameleonic disease, with involvement of the tumor microenvironment. HCC cells detach from the primary site, migrate and invade the extracellular matrix, transfer to the target organs and form metastatic lesions (4). Over 100 years ago, Paget (5) proposed the 'seed and soil theory' to explain the directional migration of cancer cells and invasion to specific organs. During tumor initiation, liver progenitor cells and hepatocytes are hypothesized to undergo genetic and epigenetic changes, which, together with disorders of the microenvironment, eventually give rise to a distinct subpopulation of cancer stem cells (CSCs) that have stem-like properties (6). Liver CSCs are considered to be responsible for HCC tumorigenesis, progression, metastasis and recurrence (7). Although significant progress has been made in the exploration of the mechanisms underlying the detachment of HCC cells, and therefore in migration and invasion, preventing HCC metastasis remains a poignant challenge for clinicians.

It has been found that chemokine networks may serve pivotal roles in inducing organ-specific metastasis (8). Chemokines are a class of small molecular proteins with similar structures, functions and chemotactic properties, and their molecular weights are $\sim 10 \mathrm{kDa}$, and chemokines represent the largest member of the cytokine family (9). At present, $>50$ chemokines have been identified, which can be divided into four families: CXC, CX3C, CC and XC, based on the different positions of the conserved $\mathrm{N}$-terminal cysteine residues (9). Chemokines bind to a variety of different receptors, which belong to the G-protein-binding receptor family, and there are $\sim 23$ types of chemokine receptors that have been discovered (10). The receptors are composed of seven 
transmembrane domains connected by extracellular and intracellular loops and transfer signals by heterotrimeric $\mathrm{Gi}$ proteins (10). Chemokines and their receptors were initially thought to allow for an interaction between immune cells and the inflammatory sites (11). After binding to the receptors, chemokines primarily serve a role in migration of leukocytes, such as monocytes, eosinophils and dendritic cells (DCs) (11). Additionally, chemokines can directly act on non-immune cells, such as tumor cells and vascular endothelial cells, to regulate the proliferation, invasion and metastasis of tumor cells to promote the progression of cancer in the tumor microenvironment (9). In addition, with the action of specific chemokines, chemotaxis of different immune cell subgroups to the tumor microenvironment is observed, which allows further regulation of the tumor immune response (12). In addition to typical chemokine receptors, chemokines can bind to the atypical chemokine receptor (ACKR) subfamily, which is a key regulator of the chemokine network, and is primarily expressed by stromal cells and endothelial cells (13). At present, ACKRs have not been shown to transmit signals, but instead function to degrade chemokines, thus controlling the extent of signal transduction (12). ACKR1 binds to $>20$ different $\mathrm{CC}$ and $\mathrm{CXC}$ chemokines (13). ACKR2 can bind to and degrade all CC family chemokines, and ACKR3 is the scavenging receptor of CXC motif chemokine ligand 12 (CXCL12) and CXCL11, which serves a key role in tumor development (14). In addition, ACKR4 primarily scavenges CC motif chemokine ligand 19 (CCL19), CCL21 and CCL25 $(15,16)$. Therefore, chemokines and their receptors can directly or indirectly shape the tumor cell microenvironment, and then affect the proliferation, invasion and metastasis of tumor cells. The association between the chemokine regulatory network and the tumor is complex and tissue-dependent. Some chemokines serve a role in promoting cancer, whereas others have a cancer-suppressing effect; for example, CCL2, CXCL10 and CX3C motif chemokine ligand 1 (CX3CL1)/CX3C motif chemokine receptor 1 (CX3CR1) can serve as favorable or unfavorable prognostic factors depending on the specific type of cancer (17). With the in-depth study of chemokines, increasing attention has been paid to the biological role and mechanism of chemokines in the occurrence and development of HCC, particularly in the process of metastasis $(12,17)$. In addition, chemokines on the exosomal surface may affect the chemotaxis of exosomes in the tumor microenvironment. The present review provides a summary of the relevant literature surrounding this topic, and discusses the association between HCC and chemokines.

\section{HCC-associated chemokines}

The morbidity ( $>20$ cases/100,000 population in East Asia) and mortality (95\%) rates of $\mathrm{HCC}$ remain high, and there are 782,000 new cases and 600,000 deaths worldwide per year (18). And the liver, one of the most common metastatic organs of tumor cells, contains multiple cellular components, such as hepatic stellate cells, macrophages and sinusoidal endothelial cells, as well as acellular components, such as matrix metalloproteinases (MMPs) $(4,19)$. Development of HCC may be associated with inflammation. Chronic liver inflammation causes continuous damage and regeneration of hepatocytes, which promotes the occurrence and development of HCC (19). Additionally, tumor-associated chronic inflammation involved the accumulation of immune cells to the tumor $(20,21)$, and chemokines serve a key role in the recruitment and activation of immune cells, and participate in tumor progression, invasion and metastasis $(22,23)$. HCC cells express a large number of chemokines and their receptors. Han et al (24) injected human hepatocellular carcinoma CBRH-7919 cells subcutaneously into nude mice, then compared the expression levels of genes involved in tumor progression between liver cancer and paracancerous tissues using chemokine microarray analysis. The results revealed that 50 chemokine-associated genes were upregulated and another 3 genes were downregulated in HCC, and western blotting confirmed the changes of CXCL1, CXCL2, CXCL3 and CXC motif chemokine receptor 1 (CXCR1) expression in a CBRH-7919 mouse model (24). Additionally, silencing of the CXCL1 gene could inhibit the growth of CBRH-7919 tumors and significantly decrease the protein expression levels of CXCL2, CXCL3 and IL-1 $\beta$ (24). Dagouassat et al (25) demonstrated that CCL2 derived from liver stromal cells mediated the migration and invasion of HCC cells. Zhang et al (26) found that liver stromal cells activated by tumors exhibited increased chemokine secretion, including CCL1-6, CCL9, CCL12, CCL25, CXCL2, CXCL10 and CXCL12, and that chemotaxis was associated with various signaling pathways, including activation of the JAK-STAT signaling pathway and T-cell receptor signaling pathway. The aforementioned studies demonstrate that chemokines and their receptors, the expression of which is frequently observed in HCC, may serve as novel therapeutic targets. Table I shows the chemokines and their receptors associated with HCC.

Unlike CXCL12 and CXCL1, CXCL16 expression in the liver decreases when a tumor metastasizes to the liver (27). Typically, CXCL16 in the liver leads to the migration of M1 macrophages to the liver, which results in apoptosis of cancer cells by secreting TNF- $\alpha$ (28). In addition, the interaction between CXCR6 and CXCL16 leads to an increase in IL-4 secretion, which activates natural killer (NK) $\mathrm{T}$ cells to inhibit the proliferation of malignant cells (27). A study on gliomas revealed that CXCL16 and CX3CL1 downregulate the expression levels of vascular endothelial growth factor C (29), suggesting that they may inhibit tumor growth by decreasing angiogenesis. However, Takiguchi et al (30) found that soluble CXCL16 produced by mesenchymal stem cells (MSCs) via Wnt5a-Ror2 increased proliferation of human gastric cancer MKN45 cells expressing CXCR6. In vivo and in vitro experiments have demonstrated that by sequestrating CCL19 and CCL21, ACKR4 (also known as CCRL1) inhibits $\beta$-catenin from entering the nucleus, blocking the Akt-GSK3 $\beta$ signaling pathway (31). Subsequently, the expression levels of cancer-promoting factors cyclin D1 and c-Myc are decreased, achieving the effect of inhibiting HCC (31). Shi et al (32) revealed that the increase of $\mathrm{CCR} 7^{+}$mononuclear cells was significantly associated with worse survival and increased recurrence, and confirmed that ACKR4 had the potential to hinder $\mathrm{CCR}^{+}$cell chemotaxis to $\mathrm{HCC}$ tissues by inhibiting CCL19 and CCL21. The aforementioned studies suggest that chemokines have different effects in the tumor microenvironment, including HCC. However, the specific roles of 
Table I. Chemokine families.

A, CXC chemokine family

\begin{tabular}{|c|c|c|c|c|c|}
\hline $\begin{array}{l}\text { Chemokine } \\
\text { receptors }\end{array}$ & Chemokines & Functions & $\begin{array}{l}\text { Signaling } \\
\text { pathways }\end{array}$ & Role in HCC & (Refs.) \\
\hline \multirow[t]{2}{*}{ CXCR1 } & \multirow[t]{2}{*}{$\begin{array}{l}\text { CXCL6, } \\
\text { CXCL7, } \\
\text { CXCL8 }\end{array}$} & \multirow[t]{2}{*}{$\begin{array}{l}\text { Chemotactic neutrophils } \\
\text { are involved in innate } \\
\text { immunity and acute } \\
\text { inflammation }\end{array}$} & - & $\begin{array}{l}\text { Up regulation of CXCL6 } \\
\text { transcription in HCC cells } \\
\text { promotes HCC progression and } \\
\text { metastasis }\end{array}$ & (108) \\
\hline & & & PI3K/Akt & $\begin{array}{l}\text { HCC plays an important role in } \\
\text { invasion and metastasis }\end{array}$ & (136) \\
\hline \multirow[t]{5}{*}{ CXCR2 } & \multirow{5}{*}{$\begin{array}{l}\text { CXCL1, } \\
\text { CXCL2, } \\
\text { CXCL3, } \\
\text { CXCL5, } \\
\text { CXCL6, } \\
\text { CXCL7, } \\
\text { CXCL8 }\end{array}$} & \multirow[t]{5}{*}{$\begin{array}{l}\text { Chemotactic neutrophils } \\
\text { guide their migration to } \\
\text { inflammatory sites }\end{array}$} & - & $\begin{array}{l}\text { CXCR2-CXCL1 axis can regulate } \\
\text { neutrophil infiltration into HCC } \\
\text { tumor tissue }\end{array}$ & (137) \\
\hline & & & ERK1/2 & $\begin{array}{l}\text { CXCL2 negatively regulates cell } \\
\text { cycle in HCC cells; } \\
\text { CXCL2 may play a key role in } \\
\text { HCC metastasis }\end{array}$ & $(89,138)$ \\
\hline & & & ERK1/2 & $\begin{array}{l}\text { Overexpression of CXCL3 was } \\
\text { significantly associated with tumor } \\
\text { capsule formation and vascular } \\
\text { invasion }\end{array}$ & (139) \\
\hline & & & $\begin{array}{l}\text { PI3K/Akt/ } \\
\text { GSK-3ß/Snail }\end{array}$ & $\begin{array}{l}\text { CXCR2/CXCL5 axis promotes } \\
\text { EMT of HCC cells; } \\
\text { CXCL5 can promote the invasion } \\
\text { and proliferation of hepatoma cells } \\
\text { by mediating the infiltration of } \\
\text { neutrophils }\end{array}$ & $(82,140)$ \\
\hline & & & $\begin{array}{l}\text { Akt/mTOR/ } \\
\text { STAT3 }\end{array}$ & $\begin{array}{l}\text { HCC serves an important role in } \\
\text { invasion and metastasis }\end{array}$ & (83) \\
\hline \multirow[t]{3}{*}{ CXCR3 } & \multirow[t]{3}{*}{$\begin{array}{l}\text { CXCL9, } \\
\text { CXCL10, } \\
\text { CXCL11 }\end{array}$} & \multirow{3}{*}{$\begin{array}{l}\text { It can promote the } \\
\text { migration of T cells, } \\
\text { promote the interaction } \\
\text { between T cells and } \\
\text { antigen presenting } \\
\text { cells, and promote the } \\
\text { production of effector } \\
\text { cells and memory cells }\end{array}$} & MAPK & $\begin{array}{l}\text { Promoting the invasion and } \\
\text { metastasis of CD133 hepatoma } \\
\text { cells }\end{array}$ & (141) \\
\hline & & & $\mathrm{c}-\mathrm{Myc}$ & $\begin{array}{l}\text { CXCL10/CXCR3 signaling } \\
\text { directly induces epithelioma } \\
\text { papulosum cyprinid } \\
\text { mobilization, differentiation and } \\
\text { neovascularization, thus further } \\
\text { promoting tumor growth }\end{array}$ & $(142,143)$ \\
\hline & & & ERK1/2 & $\begin{array}{l}\text { Promoting the self-renewal and } \\
\text { tumorigenicity of } \alpha 2 \delta 1 \text { liver tumor } \\
\text { initiating cells }\end{array}$ & (144) \\
\hline CXCR4 & CXCL12 & $\begin{array}{l}\text { It participates in the } \\
\text { migration of stem } \\
\text { cells, stimulates the } \\
\text { proliferation of B cells } \\
\text { and bone marrow cells, } \\
\text { and it is also involved in } \\
\text { the process of HIV invading } \\
\text { normal human cells. }\end{array}$ & PI3K/Akt & $\begin{array}{l}\text { CXCL12 and its receptor CXCR4 } \\
\text { promote EMT; Cancer cells } \\
\text { decrease apoptosis and achieve } \\
\text { self-renewal }\end{array}$ & (93) \\
\hline CXCR5 & CXCL13 & $\begin{array}{l}\text { Involved in B-cell } \\
\text { homing in lymphoid } \\
\text { organs }\end{array}$ & $\mathrm{Wnt} / \beta$-catenin & $\begin{array}{l}\text { CXCL13 serves an important role } \\
\text { in the development of liver cancer } \\
\text { and it may have clinical value in } \\
\text { the diagnosis and prognosis of } \\
\text { liver cancer }\end{array}$ & $(87,145)$ \\
\hline
\end{tabular}


Table I. Continued.

\begin{tabular}{llllll}
\hline $\begin{array}{l}\text { Chemokine } \\
\text { receptors }\end{array}$ & Chemokines & \multicolumn{1}{c}{ Functions } & $\begin{array}{l}\text { Signaling } \\
\text { pathways }\end{array}$ & \multicolumn{1}{c}{ Role in HCC } & (Refs.) \\
\hline CXCR6 & CXCL16 & $\begin{array}{l}\text { Promoting T-cell } \\
\text { migration }\end{array}$ & Akt/mTOR & $\begin{array}{l}\text { CXCL16 promotes HCC } \\
\text { invasiveness and tumor } \\
\text { inflammatory environment }\end{array}$ & $(105,146)$ \\
CXCR7 & CXCL11, & $\begin{array}{l}\text { Regulating the } \\
\text { development and } \\
\text { differentiation of B cells }\end{array}$ & AKT & $\begin{array}{l}\text { Overexpression of CXCR7 } \\
\text { promotes the growth and invasion } \\
\text { of HCC; } \\
\text { It plays an important role in } \\
\text { promoting angiogenesis in liver } \\
\text { cancer }\end{array}$ \\
\hline
\end{tabular}

B, CC chemokine family

\begin{tabular}{|c|c|c|c|c|c|}
\hline $\begin{array}{l}\text { Chemokine } \\
\text { receptors }\end{array}$ & Chemokine & Functions & $\begin{array}{l}\text { Signaling } \\
\text { pathways }\end{array}$ & Role in $\mathrm{HCC}$ & (Refs.) \\
\hline \multirow[t]{5}{*}{ CCR1 } & $\begin{array}{l}\text { CCL3, } \\
\text { CCL5, } \\
\text { CCL7-8, } \\
\text { CCL13, }\end{array}$ & $\begin{array}{l}\text { Chemotactic T cells and } \\
\text { monocytes are involved } \\
\text { in innate and adaptive } \\
\text { immune response and }\end{array}$ & - & $\begin{array}{l}\text { CCL3-CCR } 1 \text { axis serves an } \\
\text { important role in the invasion and } \\
\text { metastasis of } \mathrm{HCC} \text { by changing the } \\
\text { intracellular } \mathrm{Ca} \text { concentration }\end{array}$ & $(147)$ \\
\hline & $\begin{array}{l}\text { CCL14, } \\
\text { CCL15, } \\
\text { CCL16, } \\
\text { CCL23 }\end{array}$ & inflammatory response & PI3K/Akt & $\begin{array}{l}\text { CCL5 induces cell growth, } \\
\text { migration and invasion; } \\
\text { Stimulating migration and invasion } \\
\text { of Huh7 hepatoma cells }\end{array}$ & $(148,149)$ \\
\hline & & & $\begin{array}{l}\text { Inhibition of } \\
\text { Wnt } / \beta \text {-catenin }\end{array}$ & $\begin{array}{l}\text { CCL14 is a prognostic biomarker } \\
\text { associated with immune invasion } \\
\text { in } \mathrm{HCC}\end{array}$ & $(75,77)$ \\
\hline & & & STAT3/Akt & $\begin{array}{l}\text { It serves a key role in the } \\
\text { metastasis of HCC }\end{array}$ & $(136,150)$ \\
\hline & & & - & $\begin{array}{l}\text { Low CCL23 expression is not } \\
\text { conducive to the formation of } \\
\text { anti-tumor immune defense in } \\
\text { patients with liver cancer, which } \\
\text { significantly shortens the survival } \\
\text { time of patients with liver cancer }\end{array}$ & $(151)$ \\
\hline CCR2 & $\begin{array}{l}\text { CCL2, } \\
\text { CCL7, } \\
\text { CCL8, } \\
\text { CCL13 }\end{array}$ & $\begin{array}{l}\text { Mediating the expression } \\
\text { of inflammatory T-cell } \\
\text { cytokines induces } \\
\text { macrophages and } \\
\text { monocytes to recruit to } \\
\text { inflammatory sites }\end{array}$ & Hedgehog & $\begin{array}{l}\text { Regulating tumor growth, } \\
\text { metastasis and host immune } \\
\text { response to induce HCC cell } \\
\text { invasion and EMT }\end{array}$ & $(152)$ \\
\hline CCR3 & $\begin{array}{l}\text { CCL5, } \\
\text { CCL7, } \\
\text { CCL11, } \\
\text { CCL15-16, } \\
\text { CCL24, } \\
\text { CCL26 }\end{array}$ & $\begin{array}{l}\text { It serves an important } \\
\text { role in the regulation of } \\
\text { eosinophil migration }\end{array}$ & RhoB-VEGFA & $\begin{array}{l}\text { It may promote the proliferation, } \\
\text { migration and invasion of } \mathrm{HCC}, \\
\text { promote lung metastasis and } \\
\text { promote the formation of human } \\
\text { umbilical vein endothelial cells }\end{array}$ & $(153)$ \\
\hline \multirow[t]{3}{*}{ CCR4 } & $\begin{array}{l}\text { CCL17, } \\
\text { CCL22 }\end{array}$ & $\begin{array}{l}\text { Chemotactic } \mathrm{T} \text { cells and } \\
\text { monocytes migrate to the }\end{array}$ & Wnt $/ \beta$-catenin & $\begin{array}{l}\text { CCL17 promotes the occurrence } \\
\text { of HCC }\end{array}$ & $(154)$ \\
\hline & & $\begin{array}{l}\text { skin and participate in } \\
\text { allergic inflammation }\end{array}$ & - & $\begin{array}{l}\text { CCL22 contributes to Treg } \\
\text { recruitment and immunosuppression }\end{array}$ & $(155)$ \\
\hline & & & ERK/Akt/MMP2 & $\begin{array}{l}\text { CCR4 promotes HCC malignant } \\
\text { tumor and } \mathrm{HCC} \text { cell metastasis }\end{array}$ & $(156)$ \\
\hline
\end{tabular}


Table I. Continued.

\begin{tabular}{|c|c|c|c|c|c|}
\hline $\begin{array}{l}\text { Chemokine } \\
\text { receptors }\end{array}$ & Chemokines & Functions & $\begin{array}{l}\text { Signaling } \\
\text { pathways }\end{array}$ & Role in HCC & (Refs.) \\
\hline CCR5 & $\begin{array}{l}\text { CCL3, } \\
\text { CCL4, } \\
\text { CCL5, } \\
\text { CCL8 }\end{array}$ & $\begin{array}{l}\text { Mediating the chemotaxis } \\
\text { of macrophages and } \\
\text { T cells. Promoting HIV } \\
\text { penetration into normal } \\
\text { human cells. }\end{array}$ & PI3K/Akt/mTOR & $\begin{array}{l}\text { Promoting tumor occurrence and } \\
\text { development; } \\
\text { It leads to the growth, proliferation } \\
\text { and migration of hepatoma cells; } \\
\text { Regulating EMT and promoting } \\
\text { HCC metastasis }\end{array}$ & $\begin{array}{l}(157) \\
(68)\end{array}$ \\
\hline CCR6 & CCL20 & $\begin{array}{l}\text { Dendritic cells, memory } \\
\text { T cells and Th17 cells } \\
\text { were chemotactic to } \\
\text { inflammatory sites }\end{array}$ & STAT3 & $\begin{array}{l}\text { It is involved in regulating the } \\
\text { migration and invasion of } \mathrm{HCC} \text {; } \\
\text { Tregs mediate the chemotaxis } \\
\text { of Tregs to the tumor } \\
\text { microenvironment and promote } \\
\text { liver cancer }\end{array}$ & $(62,64)$ \\
\hline \multirow[t]{2}{*}{ CCR7 } & $\begin{array}{l}\text { CCL19, } \\
\text { CCL21 }\end{array}$ & $\begin{array}{l}\text { It promotes the recycling } \\
\text { of immature T cells, } \\
\text { and T cells homing to }\end{array}$ & - & $\begin{array}{l}\text { CCL19 may serve an inhibitory } \\
\text { role in the invasive regulation of } \\
\text { human HCC }\end{array}$ & (158) \\
\hline & & $\begin{array}{l}\text { the secondary lymphoid } \\
\text { tissue }\end{array}$ & Akt-GSK3 $\beta$ & $\begin{array}{l}\text { CCR } 7 \text { promotes the development } \\
\text { of } \mathrm{HCC} \text { and is associated with } \\
\text { poor survival }\end{array}$ & $(31,159)$ \\
\hline CCR8 & CCL1 & $\begin{array}{l}\text { It is involved in T-cell } \\
\text { migration and Th2 } \\
\text { response and regulates } \\
\text { monocyte chemotaxis and } \\
\text { thymocyte apoptosis }\end{array}$ & PKM2-ARRDC1 & $\begin{array}{l}\text { CCL1/CCR8 axis promotes PKM2 } \\
\text { excretion in HCC cells }\end{array}$ & $(160)$ \\
\hline CCR9 & CCL25 & $\begin{array}{l}\text { Regulation of lymphocyte } \\
\text { epithelial interaction } \\
\text { in small intestinal } \\
\text { mucosa; Involved in } \\
\text { multiple stages of adult } \\
\text { T lymphocyte production }\end{array}$ & - & $\begin{array}{l}\text { It is concluded that the } \\
\text { regulation of multiple EMT } \\
\text { markers serves an important } \\
\text { role in the migration and } \\
\text { invasion of HCC cells, } \\
\text { enhances the colony forming } \\
\text { ability of hepatoma cells and } \\
\text { their tumorigenicity, and is an } \\
\text { independent prognostic factor for } \\
\text { the overall survival of patients } \\
\text { with HCC }\end{array}$ & $(161)$ \\
\hline CCR 10 & $\begin{array}{l}\text { CCL27, } \\
\text { CCL28 }\end{array}$ & $\begin{array}{l}\text { Key regulators of skin } \\
\text { immune homeostasis; } \\
\text { Regulating intestinal IgA } \\
\text { response and memory } \\
\text { maintenance }\end{array}$ & PI3K/Akt & $\begin{array}{l}\text { Inflammation drives } \\
\text { hepatocarcinogenesis }\end{array}$ & $(60)$ \\
\hline
\end{tabular}

C, CX3C chemokine family

\begin{tabular}{|c|c|c|c|c|c|}
\hline $\begin{array}{l}\text { Chemokine } \\
\text { receptors }\end{array}$ & Chemokine & Functions & $\begin{array}{l}\text { Signaling } \\
\text { pathways }\end{array}$ & Role in HCC & (Refs.) \\
\hline CX3CR1 & CX3CL1 & $\begin{array}{l}\text { Chemotactic lymphocytes } \\
\text { and macrophages; It also } \\
\text { has a chemotactic effect } \\
\text { on microglia }\end{array}$ & $\begin{array}{l}\text { STAT3 } \\
\text { Src/PTK2 }\end{array}$ & $\begin{array}{l}\text { CX3CL1 stimulates chemotaxis } \\
\text { and cytotoxicity of CX3CR1 } \\
\text { natural killer cells; } \\
\text { CX3CL1 induces invasion and } \\
\text { migration of HCC cells into the } \\
\text { spine }\end{array}$ & $(34,39)$ \\
\hline
\end{tabular}


Table I. Continued.

$\mathrm{D}, \mathrm{XC}$ chemokine family

\begin{tabular}{|c|c|c|c|c|c|}
\hline $\begin{array}{l}\text { Chemokine } \\
\text { receptors }\end{array}$ & Chemokine & Functions & $\begin{array}{l}\text { Signaling } \\
\text { pathways }\end{array}$ & Role in $\mathrm{HCC}$ & (Refs.) \\
\hline XCR 1 & $\begin{array}{l}\text { XCL1, } \\
\text { XCL2 }\end{array}$ & $\begin{array}{l}\text { Establishment of } \\
\text { regulatory thymic } \\
\text { tolerance and production } \\
\text { of Tregs }\end{array}$ & $\begin{array}{l}\text { MAPK and } \\
\text { PI3K/Akt }\end{array}$ & $\begin{array}{l}\text { High XCR1 expression is } \\
\text { positively associated with EMT, } \\
\text { which is closely associated with } \\
\text { tumor migration and invasion }\end{array}$ & (48) \\
\hline
\end{tabular}

HCC, hepatocellular carcinoma; EMT, epithelial-mesenchymal transition; Tregs, regulatory T cells; Th, Thelper; HIV, human immunodeficiency virus.

chemokines in different cellular microenvironments and the underlying mechanisms require further study.

$C X 3 C$. As the only member of the CX3C chemokine subfamily, CX3CL1 is a transmembrane glycoprotein that exists in two forms: Membrane-bound and secretory. In addition, the mucin-like domain of CX3CL1 contains a cleavage site that allows metalloproteinases (such as ADAM10) to cleave and release proteins in a soluble form (33). CXCR3 is the only receptor of CX3CL1, and CX3CL1/CX3CR1 regulates the chemotaxis of inflammatory cells, as well as the proliferation, migration and invasion of cancer cells $(34,35)$. It has been reported that CX3CL1 is closely associated with the metastasis of prostate (36) and breast cancer (37). Additionally, these studies confirmed that inhibition of CX3CL1 was an effective strategy to prevent spinal metastasis of breast and prostate cancer $(36,37)$. Sun et al (34) revealed that CX3CL1/CX3CR1 expression in HCC spinal metastases was upregulated. Bone marrow endothelial cells promote the migration and invasion of Hep3B and MHCC $97 \mathrm{H}$ cells to the spine by secreting soluble CX3CL1 and this is inhibited following neutralization of CX3CL1 (34). In CX3CR1 gene-deficient mice, Zheng et al (38) found that the metastasis of colon cancer cells to the liver was significantly suppressed, and the upregulation of CX3CR1 gene expression in tumor-associated cells was associated with worse prognosis. Additionally, it was confirmed that CX3CR1 deficiency inhibited macrophage aggregation and promoted macrophage apoptosis in metastatic tumors, thus serving an antitumor effect (38). Considering the dual functions of CX3CL1 as a chemoattractant for leukocytes and adhesion molecules for tumor cells, CX3CL1 may have dual effects, promoting tumor progression or antitumor effects (35). Chen et al (39) found that the increase of CX3CL1 expression levels were associated with liver metastasis and poor prognosis after hepatectomy. Additionally, it was shown that miR-561-5p downregulated CX3CL1 mRNA expression, leading to a decrease in chemotaxis, functional regulation and infiltration of $\mathrm{CX} 3 \mathrm{CR} 1^{+} \mathrm{NK}$ cells, thus promoting $\mathrm{HCC}$ growth and lung metastasis (39). Miao et al (40) demonstrated that members of the $\mathrm{CX} 3 \mathrm{CR} 1 / \mathrm{Syk} / \mathrm{PI} 3 \mathrm{~K}$ signaling pathway were essential for CX3CL1-induced platelet migration, which induced apoptosis of HCC cells in vitro, thus inhibiting HCC growth. These studies suggest that CX3CL1/CX3CR1 are potential therapeutic targets against $\mathrm{HCC}$ growth and metastasis. Interference with CX3CL1/CX3CR1 may have future clinical implications for HCC prevention and treatment.

$X C$. Among the four types of chemokines, there are two highly homologous XC chemokines: XC motif chemokine ligand 1 (XCL1) and XCL2, whose genes (SCYC1 and SCYC2, respectively) are located on chromosome 1 . There are only two amino acid differences between them, and XCL1 is the variant with the predominant effect (41). Unlike CXC, CC and $\mathrm{CX} 3 \mathrm{C}$ chemokines with two disulfide bonds and four cysteine residues at the $\mathrm{N}$-terminal, XCL1 has only one disulfide bond and two cysteine residues (42). XC motif chemokine receptor 1 (XCR1) is the receptor of XCL1, and human XCR1 is primarily expressed in $\mathrm{BDCA}^{+} / \mathrm{CD} 141^{+} \mathrm{DCs}$, which serve an important role in antigen presentation and enhancing cytotoxic T-cell response (43). Similar to other family members, XCR1 serves an important role in human tumors. Several studies have revealed that XCR1 expression is upregulated in ovarian, oral and breast cancer, where it promotes cancer cell proliferation, adhesion, migration and invasion (44-46). For example, Kim et al (46) found that XCR1 was expressed in both primary and metastatic human epithelial ovarian cancer specimens and cell lines, but not in normal ovaries or ovarian surface epithelial cells, highlighting the association between XCR1 and cell carcinogenesis and migration. Wang et al (47) revealed that XCL1/XCR1 significantly promoted the proliferation and migration of lung cancer cells, whereas the role of XCL1 in cell proliferation and migration was abrogated following XCR1-knockdown using small interfering RNA. However, not all studies support this conclusion. Another study assessed XCR1 expression in an HCC cell line and on the proliferation, metastasis and invasive ability of HCC (48). In vitro, it was found that XCR1 silencing promoted the migration and invasion of HCC, whereas the overexpression of XCR1 had the opposite effect, and the mechanism may be associated with the inhibition of epithelial-mesenchymal transition (EMT) (48). Additionally, overexpression of XCR1 in HCCLM3 cells decreased tumor growth, partially due to the inhibition of the MAPK and PI3K/Akt signaling pathways (48). The aforementioned studies indicate that XCR1 may have different roles in different tumors and thus warrants further study.

It has been demonstrated that $\mathrm{XCR} 1^{+} \mathrm{DCs}$ can promote the antitumor immune response and lead to tumor cell death (49). Using a fusion protein composed of a tumor antigen and XCL1 
to target and activate $\mathrm{XCR} 1^{+} \mathrm{CD} 141^{+} \mathrm{DCs}, \mathrm{CD} 8^{+} \mathrm{T}$-cell activation was induced to elicit an antitumor effect (50). In humans, high quantities of $\mathrm{CD} 141^{+}$DCs are associated with improved prognosis (51). In another study, fusion proteins composed of XCL1 fused to an ovalbumin (OVA) synthetic long peptide and IgG1 Fc fragment was established; the specific binding and uptake of XCL1 fusion protein by $\mathrm{XCR}^{+} \mathrm{DCs}$ enhanced the response of $\mathrm{CD}^{+} \mathrm{T}$ cells and delayed the progression of B16-OVA melanoma (52). Chen et al (53) constructed a fusion molecule of XCL1 as a liver cancer vaccine by creating a fusion of XCL1 with glypican-3 (GPC3). The cells expressing XCL1-GPC3 were chemotactic and attracted mouse $\mathrm{XCR} 1^{+} \mathrm{CD} 8 \alpha^{+} \mathrm{DCs}$ and human $\mathrm{XCR} 1^{+} \mathrm{CD} 141^{+} \mathrm{DCs}$, to promote the production of IL12 in vitro (53). XCL1-GPC3-targeted DCs can enhance the proliferation of antigen-specific CD8 ${ }^{+}$ $\mathrm{T}$ cells and induce the regeneration of GPC3-specific $\mathrm{CD}^{+}$ $\mathrm{T}$ cells, thus decreasing the development of HCC via GPC3 expression in mouse and human systems (53). At present, several clinical trials have been performed assessing the biology and therapeutic potential of DCs, but thus far, their clinical applications have remained unsatisfactory. It has been hypothesized that $\mathrm{XCR}^{+}$cross-presentation subsets may be used as a potential target of next generation DC-based therapy, as $\mathrm{XCR}^{+} \mathrm{DCs}$ have the unique ability to stimulate $\mathrm{CD} 8^{+} \mathrm{T}$ cells and regulate antitumor effects $(54,55)$. Taking the most effective intervention measures to enhance the migration, activation, maturity and function of $\mathrm{XCR} 1^{+} \mathrm{DCs}$ is essential to fully exert their anticancer potential. Targeting $\mathrm{XCR} 1^{+} \mathrm{DCs}$ using a fusion protein of various antigens, including neoantigens and human XCL1/2, may exhibit potential as promising anticancer vaccines.

$C C$. The CC chemokine subfamily consists of $>20$ members, and the $\mathrm{N}$-terminal of the members contain two adjacent cysteine residues (9). CC chemokines serve indispensable roles in HCC. It has been demonstrated that CCL2 promotes HCC invasion and the effect of EMT, accompanied by the activation of the Hedgehog signaling pathway (56). Additionally, CCL2 can stimulate angiogenesis and further promote the progression of liver cancer (56). The combination of CCL2 with CCR4 ${ }^{+}$ regulatory $\mathrm{T}$ cells (Tregs) and $\mathrm{CCR} 2^{+} \mathrm{Ly}-6 \mathrm{C}^{+}$myeloid-derived suppressor cells (MDSCs) affects the glioma microenvironment and causes immunosuppression, thus promoting tumor development, which indicates that CCL2/CCR2 and CCL2/CCR4 serve a crucial role in inducing the migration of monocytic-MDSCs to precancerous lesions $(57,58)$. Qi et al (59) confirmed that CCL7 and its receptor CCR3 were key mediators of invasion and metastasis of lung and colon tumor cells. CCL7 modulates signal transmission by binding to CCR1, CCR 2 and CCR3, the expression levels of which are upregulated in liver metastases, with CCR3 exhibiting higher expression levels than CCR1 or CCR2 (59). Furthermore, it was revealed that CCL7 regulated the transport of MMP-9 to invasive cells through its receptor CCR3, thus promoting the formation of functional invasive cells, degrading collagen and invading extracellular matrix, a key condition for HCC migration (59). Via targeted gene expression microarray screening alterations in G-protein coupled receptor family gene expression, Wu et al (60) found that CCR10 was significantly upregulated in inflammation-driven HCC tumors and paracancerous tissue hepatocytes. Additionally, CCR10, secreted by hepatocytes, activates the PI3K/Akt signaling pathway via Akt phosphorylation, and inhibits apoptosis and promotes compensatory proliferation to drive the occurrence of HCC (60). CCR6 is another member of the CC chemokine receptor family, and its ligand CCL20 is also known as macrophage regulatory protein $3 \mathrm{a}(20)$. It has been reported that CCR6 is highly expressed in a variety of cancer cells and participates in different tumor-associated behaviors (61). Several studies have demonstrated that CCL20/CCR6 promotes the proliferation, adhesion and chemotactic migration of HCC cells $(62,63)$. CCL20 mediates the chemotaxis of Tregs to the tumor microenvironment and this process is achieved via the activation of STAT3 (64). Furthermore, the expression of epidermal growth factor receptor/Ras-induced CCL20 in the tumor microenvironment stimulates tumor microangiogenesis, leading to rapid tumor growth and progression (64). Blocking the activity of CCR6 in the tumor microenvironment may inhibit tumor neovascularization and enhance traditional antitumor therapy (61). CCR6, the specific receptor of CCL20, may be a promising anticancer target. Other $\mathrm{CC}$ members, such as CCL28, promote the infiltration of Tregs into the tumor environment, induce angiogenesis and facilitate tumor cell escape from immune surveillance (65). Gao et al (66) reported that CCL15 secreted by HCC cells can promote chemotaxis to cancer foci by binding to CCR1 on the membrane of MSCs. Although unmodified MSCs have no significant effect on the progression of HCC tumors, they are considered to be a promising gene delivery vector in tumor therapy (66). In addition, due to the similar phenotypes of $\mathrm{CCR} 7^{+}$monocytes and Tregs, they can both promote tumor progression by producing TGF- $\beta 1$ (32). The aforementioned studies highlight novel therapeutic targets for the treatment of HCC.

CCL5 can bind to CCR1 and CCR3, but the activity of CCL5 is exerted by binding to CCR5 $(63,67)$. CCL5/CCR5 expression in HCC tissues is significantly higher compared with in non-neoplastic liver tissues, and CCL5 binding to CCR 5 activates the PI3K/Akt/mTOR signaling pathway, which is associated with the occurrence and development of HCC, and the CCR5 antagonist, maraviroc, reverses this effect (67). Additionally, CCL5/CCR5 regulates EMT, promoting HCC metastasis (68). Furthermore, macrophages exposed to hepatitis $\mathrm{C}$ virus exhibit increased secretion of CCL5, which further activates hepatic stellate cells to induce hepatitis and liver fibrosis (69), highlighting the biological and clinical significance of CCL5/CCR5 in the development of HCC. As CCR5 exists in immune cells and cancer cells, it can exert dual effects, both antitumor and tumor-promoting effects (70). Thus, the function of CCL5/CCR5 remains controversial. However, in general, CCL5/CCR5 serves a major role in promoting tumors (68). These findings suggest that CCL5/CCR5 may be a potential target for the treatment of HCC.

The CC subfamily is also associated with tumor drug resistance. In lung cancer, CCL2 is associated with docetaxel resistance via activation of the PI3K/Akt signaling pathway where it inhibits caspase3-dependent apoptosis (71). In addition, stroma-derived CCL2 and CCL5 induce tumor cells to release IL-6 by activating the PYK2 signaling pathway (located upstream of the JAK1/STAT3 signaling pathway), thereby resulting in carboplatin resistance (72). Similarly, the regulation of CCL20 expression via ATP-binding cassette 
subfamily B member 1 membrane transporter is associated with doxorubicin resistance (73). Vaquero et al (74) examined 109 genes that may be associated with chemotherapeutic drug resistance in HCC and found that CCL14 and CCL15 mRNA expression was upregulated following activation of nuclear receptor FXR; this upregulation was involved in drug resistance and the mechanism of chemoresistance (MOC) may be associated with changes in the balance of apoptosis-promoting (MOC-5a) and survival-promoting (MOC-5b) genes. By detecting the expression levels of $\mathrm{CC}$ chemokines associated with drug resistance and by performing targeted blocking, the efficacy of chemotherapy drugs may be improved.

Not all CC subfamily chemokines promote tumor progression. Gu et al (75) found that CCL14 expression in certain types of human cancer was significantly lower compared with in normal tissues, such as in HCC. Low CCL14 expression is associated with improved overall survival, disease-specific survival, progression-free survival and recurrence-free survival in patients with HCC, particularly in the early stages of disease, and CCL14 is strongly associated with tumor infiltrating B cells, $\mathrm{CD}^{+}$and $\mathrm{CD} 8^{+} \mathrm{T}$ cells, DCs, neutrophils and macrophages (75). CCL14 binds to chemokine receptors such as CCR1, CCR3 and CCR5, and regulates the activation and migration of different leukocytes by mobilizing $\mathrm{Ca}^{2+}$ influx (76). CCL14 expression in HCC is negatively associated with the expression levels of several immune cell markers, including programmed death receptor-1, T-cell immunoglobulin mucin-3 and cytotoxic T-lymphocyte associate protein-4, suggesting the role of CCL14 in tumor immune regulation (75). Zhu et al (77) used tissue microarrays to analyze CCL14 expression in tumor and paracancerous tissues, revealing that CCL14 expression was downregulated in liver cancer tissues compared with in the surrounding tissues. Overexpression of CCL14 inhibits the proliferation of HCC and promotes apoptosis (77). Additionally, the results of animal experiments confirmed that CCL14 could inhibit the growth of tumors in nude mice and notably, experimental data suggest that CCL14 may exert these effects by inhibiting the activation of the Wnt/ $\beta$-catenin signaling pathway (77). Zhang et al (78) confirmed that CCL14 was stable and effective in predicting the survival rate and recurrence time of patients with $\mathrm{HCC}$ via RNA sequencing analysis of 330 specimens. These findings suggest that CCL14 may be used as a biomarker to predict the prognosis of patients with $\mathrm{HCC}$ and may be a potential target for the treatment of HCC.

In summary, CC subfamily chemokines are increasingly considered to be involved in a variety of tumor biological processes, and are closely associated with the development, metastasis and regulation of the tumor microenvironment of HCC.However,further studies and noveltechniques/therapeutics are required to improve the diagnosis and treatment of $\mathrm{HCC}$ effectively via regulation of $\mathrm{CC}$ subfamily chemokines.

CXC. In normal liver tissues, CXC chemokines are widely involved in the repair of hepatocyte injury by affecting hepatocyte proliferation and regeneration (79), and they serve an important role in the occurrence and development of HCC and the tumor microenvironment. Although the ligands and receptors have high sequence homology $(\sim 80 \%)$, the ligand selectivity of receptors varies, and CXC chemokines are divided into two groups according to the presence or absence of Glu-Leu-Arg (ELR motif) at the amino terminal, which exerts a vital effect on tumorigenesis and development, particularly in tumor angiogenesis (80). Members containing the ELR motif (including CXCL1, 2, 3, 5, 6,7 and 8) bind to CXCR2 and exert angiogenic effects, whereas most CXC chemokines without the ELR motif bind to CXCR3 and lead to vascular inhibition (80). For example, the CXCL5/CXCR2 axis is involved in EMT in HCC by activating the PI3K/Akt/GSK-3 $\beta /$ Snail signaling pathway and significantly enhances the proliferative, migratory and invasive abilities of HCC cells $(81,82)$. CXCL8, also known as IL-8, is usually secreted by tumor cells and inflammatory cells (12). In HCC, the levels of CXCL8 are significantly increased compared with in normal liver tissue, leading to progression and metastasis by activating the AKT/mTOR/STAT3 signaling pathway (83).

Studies have shown that neutrophils expressing CXCR2 chemotactically enter the liver by binding to CXCL1 (84), releasing MMP8 and MMP9 to induce angiogenesis (85). Additionally, CXCL8 increases immune infiltration of Tregs into the tumor microenvironment (22). Therefore, evaluating the expression levels of chemokines in the liver may be a prognostic factor for follow-ups in patients with HCC. CXCL10 expression is positively associated with increased serum $\alpha$-fetoprotein levels, tumor size, tumor number and TNM stage (86). Kaplan-Meier survival curve analyses revealed that the overall survival rate and disease-free survival rate of patients with high CXCL10 expression was low; additionally, univariate/multivariate analyses demonstrated that CXCL10 was an independent prognostic factor for patients with HCC (86). By measuring the levels of CXCL13 in patients with $\mathrm{HCC}, \mathrm{Li}$ et al (87) found that CXCL13 levels in patients with tumors $>5 \mathrm{~cm}$ were significantly higher compared with those in patients with tumors $<5 \mathrm{~cm}$ in size, and the levels of CXCL13 were positively associated with Child-Pugh score and negatively correlated with albumin and cholinesterase levels. It has been suggested that CXCL13 may be used as an index to evaluate liver function (87). Song et al (88) reported that CXCL2 expression was upregulated in the blood of patients with HCC and promoted the proliferation and metastasis of HepG2 and PG5 cells. Conversely, Ding et al (89) overexpressed CXCL2 in MHCC97H and HCCLM3 cell lines using lentiviral transfection, and revealed that the exogenous expression of CXCL2 inhibited cell proliferation by promoting apoptosis and cell cycle arrest at the $\mathrm{G}_{1}$ phase. Additionally, Subat et al (90) found that CXCL2 levels were significantly downregulated in tumor tissues compared with in normal liver tissues, but high CXCL2 expression was positively associated with the number of HCC tumors. This may be due to different molecular mechanisms of occurrence and development in different tumor cell lines.

The role of CXCL12 is very important in the development of HCC. In the past, it was considered that CXCR4 was the only receptor of CXCL12. CXCL12/CXCR4 binds specifically and is commonly involved in various pathophysiological processes, such as anti-apoptotic and angiogenesis processes (29). Additionally, CXCL12/CXCR4 serves a key role in cell migration to multiple organs, including the liver, bone marrow and lungs (91). Additionally, CXCL12/CXCR4 can promote EMT (92), decrease apoptosis and allow for self-renewal of cancer cells by activating the anti-apoptotic 


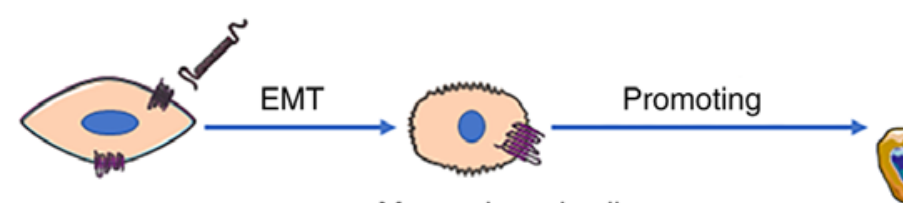

Epithelial cell
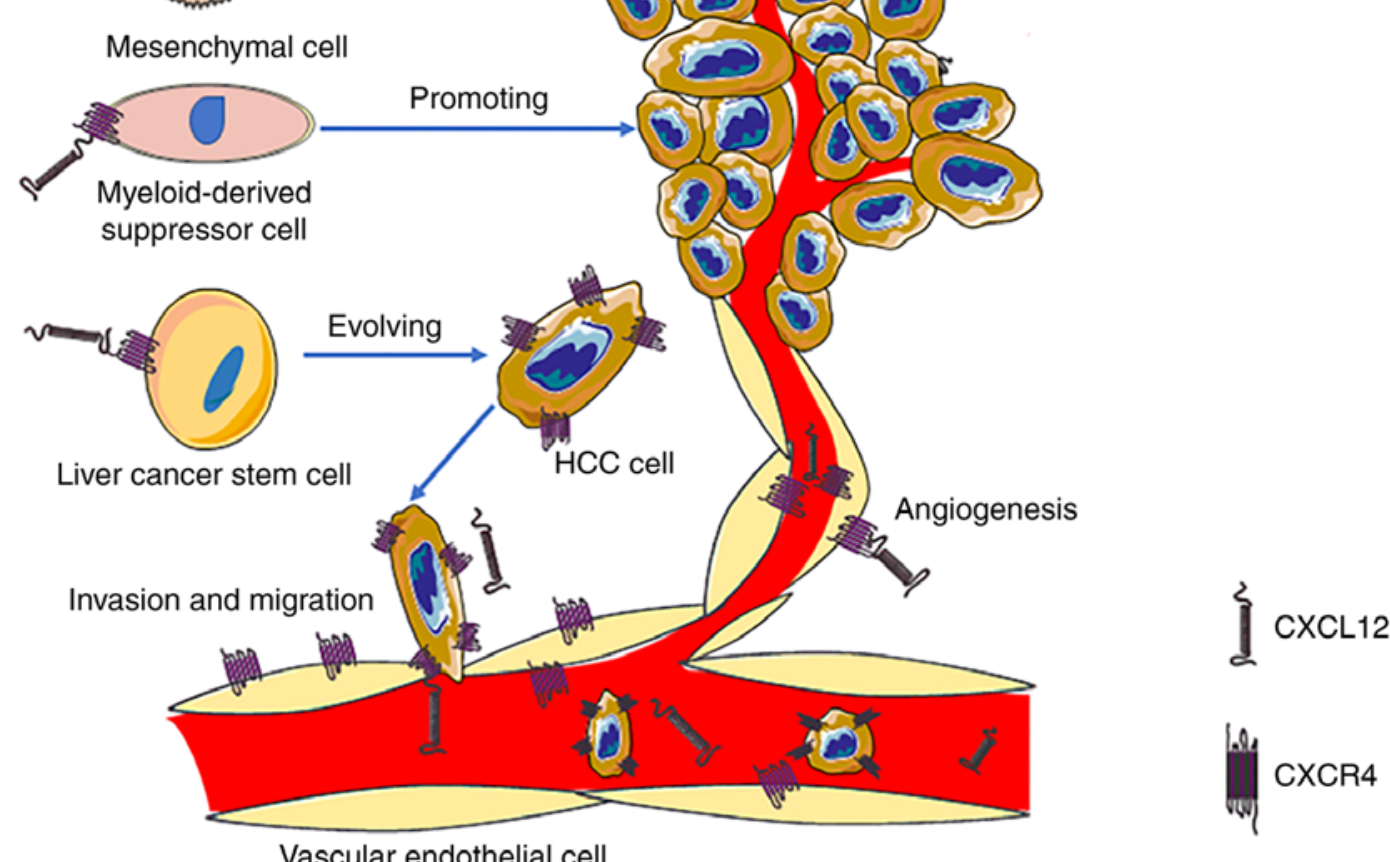

Figure 1. CXCL12/CXCR4 can induce angiogenesis, EMT and myeloid-derived suppressor cells to promote the progression of HCC. Additionally, CXCL12/CXCR4 expression enhances the activity of $\mathrm{OV}^{+}$liver cancer stem cells via the Wnt/ $\beta$-catenin signaling pathway, thus enhancing invasion and migration of HCC. In addition, CXCL12/CXCR4 can directly promote HCC growth and metastasis. CXCL12, CXC motif chemokine ligand 12; CXCR4, CXC motif chemokine receptor 4; EMT, epithelial-mesenchymal transformation; HCC, hepatocellular carcinoma; OV6, oval cell marker.

PI3K/Akt signaling pathway (93), increase the expression levels of hypoxia-inducible factor and activate MMPs, thereby jointly promoting angiogenesis and cancer metastasis $(94,95)$. Wang et al (96) found that the hepatitis B virus (HBV) X protein (HBx) enhanced MDM2 expression by directly binding to MDM2 and inhibiting its ubiquitin degradation, resulting in enhanced transcriptional activity and CXCL12 and CXCR4 expression, which in turn activated the Wnt/ $\beta$-catenin signaling pathway and enhanced the activity of $\mathrm{OV}^{+} \mathrm{CSCs}$. In addition, the aforementioned study indicated that the expression levels of any two markers of the HBx/MDM2/CXCR4/OV6 axis in $\mathrm{HCC}$ biopsies could be used to predict the prognosis of patients with HBV-associated HCC (96). Another study demonstrated that the occurrence rate of CXCR4 in the blood vessels of liver cancer was $\sim 50 \%$, and that high CXCR4 expression indicated a poor prognosis (97). These results suggest that CXCR4 may be a prognostic factor and a potential therapeutic target for HCC (Fig. 1). Knocking down CXCR4 gene expression using small interfering RNA results in decreased invasiveness of uveal melanoma cells exposed to soluble factors produced by the human liver (98). The U.S. Food and Drug Administration has approved the CXCR4 antagonist plerixafor (Mozobil, AMD3100) for peripheral blood stem cell mobilization following an autologous transplantation (99). In addition, Collins et al (100) hypothesized that CXCL14 may be a positive allosteric modulator of CXCR4, enhancing the potency of CXCR4. CXCR7 is another high affinity receptor of CXCL12, which activates the Akt signaling pathway to induce angiogenesis in HCC (101) and stimulates MAPK signal transduction to promote HCC growth and invasion (102). These studies suggest that CXCL12 and its receptors serve a role that cannot be ignored in the development of HCC.

CXCR3 is expressed in almost all cells, is upregulated in several types of primary and metastatic tumors (such as renal cancer, colon cancer and pulmonary metastasis tumor), and is considered to be essential for migration of cancer cells $(12,103)$. Three variants of CXCR3 (CXCR3-A, CXCR3-B and CXCR3-alt) have been identified, and two of these, CXCR3-A and CXCR3-B, induce opposing physiological functions (103). Overall, CXCR3-A promotes cell proliferation, survival, chemotaxis, invasion and mediates tumor metastasis, whereas CXCR3-B inhibits tumor growth and promotes apoptosis and angiogenesis (104). Therefore, abnormal expression levels of CXCR3-A and CXCR3-B can affect the progression of a tumor. Compared with CXCR3-A, CXCR3-alt possesses a substantially different C-terminal protein sequence, which differs from all known chemokine receptors (104). However, there are few studies on CXCR3-alt (104). At the cellular level, it has been shown that knocking down CXCR3 significantly inhibits the proliferation, adhesion, migration and invasion of HCC cells (86). Gao et al (105) reported that high CXCR6 expression promotes the invasion of $\mathrm{HCC}$ and the generation of an inflammatory environment, and is associated with a poor prognosis in patients with HCC. These results support the view that inhibition of the CXCL16/CXCR6 pathway may improve the prognosis of HCC treatment. CXCR7 is highly expressed in tumor endothelial cells, enhancing HCC migration and invasion by affecting the phosphorylation of the 
STAT3 signaling pathway (106). The aforementioned studies suggest that targeted therapy for chemokine receptors may be a potential direction for the diagnosis and treatment of HCC.

MDSCs regulate the immunosuppressive network and participate in all aspects of tumor progression, and their migration is associated with autocrine or paracrine chemokines (58). Xu et al (107) reported that hematopoietic stem cells (HSCs) induce an increase in the number of MDSCs in HCC lesions. Further animal experiments revealed that activated HSCs secrete CCL2, CXCL1, CXCL5 and CXCL12 by binding to the MDSC membrane surface receptors CCR2, CXCR2 and CXCR4 to mediate MDSC migration (108). Additionally, Zhang et al (26) found that CCL2 and CXCL12 produced by tumor-associated liver stromal cells contribute to the accumulation of MDSCs and promote HCC growth. This highlights a potentially effective means of altering the tumor microenvironment by regulating the secretion of chemokines from liver mesenchymal cells.

\section{Chemokines, exosomes and HCC}

Exosomes are microvesicles secreted by cells with a diameter of 30-100 nm (109) which are widely present in several body fluids, such as serum, milk, semen and malignant effusions (110). As intercellular messengers, exosomes are involved in the occurrence, development and metastasis of tumors, participating in several biological processes, such as the inflammatory immune response, cell survival and apoptosis, angiogenesis, thrombosis, autophagy and intercellular signal communication (111-113). The multiple functions of exosomes have attracted wide attention in the past few decades. Exosomes mediate the transport of proteins, DNA and various forms of RNA, such as microRNAs (miRs), long non-coding RNAs and mRNAs, between cells, thus promoting the occurrence and development of HCC $(114,115)$. Sun et al (116) demonstrated that miR-155 was enriched in the exosomes released by HCC cells, and the exosomes rich in miR-155 entered new liver tumor cells and promoted the proliferation of HCC cells. Compared with conventional liposomes, exosomes have low toxicity, low immunogenicity and good bioavailability (117). For example, previous studies reported that exosomes produced by HeLa cells, DCs and MSCs did not induce an inflammatory response $(118,119)$. Therefore, the use of modified exosomes as a drug carrier to deliver drugs to the tumor to improve drug availability and decreased side effects has been proposed (120). As an example, paclitaxel was integrated into exosomes released by macrophages to treat multidrug-resistant cancers (121). Compared with free drugs, the cytotoxicity of exosome-mediated transport of drugs into drug-resistant cells increased by $>50$ times (121). However, there are still certain technical obstacles to overcome before these approaches can be implemented in clinical practice, such as challenges on the stability of this components, as well as a lack of targets (122). It is generally hypothesized that exosomal membrane surface proteins bind to the receptors of the target cell, then transport the cargo into the cell (123). In order to better target cells, and improve the stability of exosomes in vivo, surface modifications are required. With the development of new technologies, studies have used efficient surface labeling technology to manufacture monoclonal antibody $(\mathrm{mAb})$ exosomes $(124,125)$. Flow cytometry and confocal laser scanning microscopy revealed that SSTR2 mAb-exosomes and SSTR-overexpressing neuroendocrine cancer cells exhibited strong bonding; additionally, in vitro and in vivo studies confirmed that SSTR2 $\mathrm{mAb}$-exosomes effectively delivered romidepsin to tumor cells (122). Compared with the control group, the treatment group exhibited delayed tumor progression and exhibited low toxicity and minimal side effects (122). It has been confirmed that integrins expressed on exosomes serve an important role in promoting the uptake of tumor-derived exosomes by endothelial cells and MSCs $(126,127)$. Hoshino et al (128) reported that different exosomes expressed different integrins, which determined the chemotaxis of exosomes to specific organs. After loading sorafenib into exosomes modified by glucose-related protein 78 small interfering RNA secreted by bone marrow-derived MSCs, Li et al (129) found that these exosomes enhanced drug loading in drug-resistant HCC, as well as preventing the development and metastasis of cancer cells, indicating that the modified exosomes have attractive chemotaxis properties. These studies suggest that modified exosomes exhibit broad potential for drug delivery in specific types of cancer.

Whether chemokines are expressed on the surface of exosomes, and whether they promote the chemotaxis of exosomes to HCC has been investigated. Viñas et al (130) observed that CXCL12 expression in kidneys was increased and that exosomes expressing CXCR4 were enriched in mice with renal ischemia/reperfusion injury. Further experiments revealed that hypoxia promoted CXCL12 expression in human umbilical vein endothelial cells (HUVECs) (130). Compared with normal cells, HUVECs exposed to hypoxia exhibited increased uptake of CXCR4-expressing exosomes, and was significantly inhibited by the CXCR4 inhibitor plerixafor (130). The aforementioned study revealed the effect of CXCL12/CXCR4 in the chemotaxis of exosomes to kidney endothelium. Additionally, Ciullo et al (131) found that in a mouse model of cardiac ischemia-reperfusion, compared with the exosomes that did not express CXCR4, the exosomes expressing CXCR4 migrated more effectively using chemotaxis to the CXCL12-expressing cardiomyocytes and exerted improved cardioprotective effects. Gao et al (132) found that the accumulation of exosomes produced by mature DCs in the spleen is regulated by CCR7 on the exosomal membrane surface. A decrease in CCR7 expression decreases the accumulation of exosomes in the spleen and decreases the inflammatory reaction (132). In HCC, CXCL12 expression is significantly increased compared with in normal liver tissues (107). Theoretically, the exosomes expressing CXCR4 may more effectively induce chemotaxis to HCC and thus serve a role in targeted drug delivery. Thus, it was hypothesized that the surface of modified HCC exosomes overexpressing chemokine receptors, such as CXCR4, and loaded with antitumor drugs, may enhance the chemotaxis of exosomes to HCC and achieve the goal of targeted therapy (Fig. 2). Although exosomes have received widespread attention, studies on this subject remain limited, and the complexity of exosomes in the treatment of liver cancer is not fully understood. In future studies, the association between exocrine chemotaxis and chemokines should be further determined to lay the foundation for the study of exosome-directed drug delivery to the liver. 


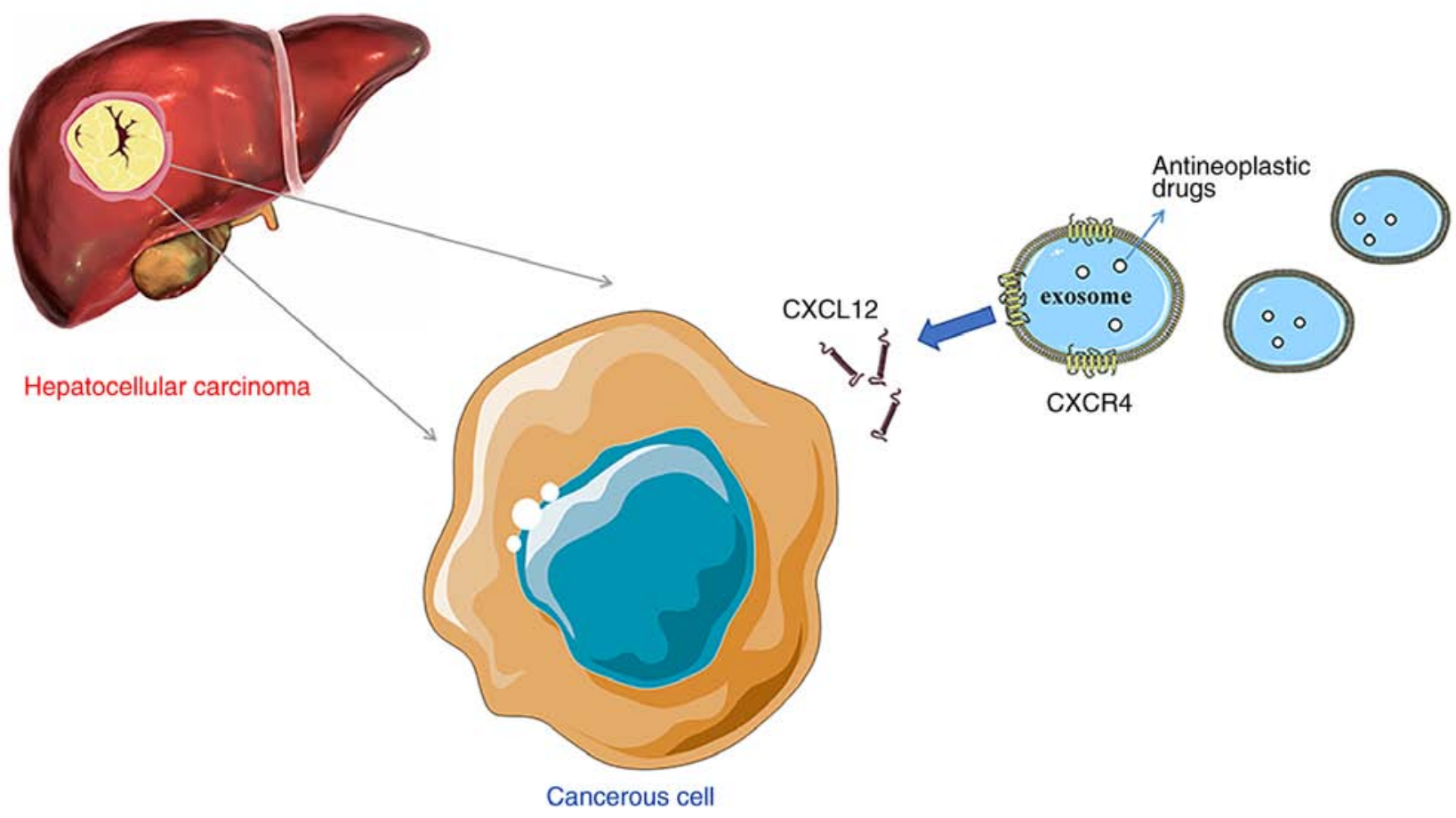

Figure 2. Exosomes in targeted therapy of hepatocellular carcinoma. Exosomes expressing chemokine receptors enhance chemotaxis to target organs overexpressing corresponding chemokines. The present review hypothesized that the surface of hepatocellular carcinoma exosomes may be modified to overexpress chemokine receptors, such as CXCR4, and may be loaded with antitumor drugs, to enhance the chemotaxis of exosomes to hepatocellular carcinoma and achieve the goal of targeted therapy. CXCL12, CXC motif chemokine ligand 12; CXCR4, CXC motif chemokine receptor 4.

\section{Conclusions and future prospects}

There is an urgent need to identify novel therapeutic strategies for the management of HCC due to the poor prognosis of patients. In recent years, immunotherapy and molecular targeted therapy have become increasingly popular. However, the unique immune response in the liver favors tolerance, which represents a substantial challenge for conventional immunotherapy in patients with HCC (133). Altering the tumor microenvironment and preventing immune tolerance are the goals of novel immune-based methods. HCC typically develops alongside or following various other liver diseases (such as hepatitis and cirrhosis), in which the constant inflammation process enhances the formation and growth of the tumor (134). In a review by Gnoni et al (4), it was suggested that the cells present in the microenvironment, such as macrophages, activated stellate cells and blood (platelets) cells, contribute to stimulate and enhance tumorigenesis, angiogenesis and metastases of HCC. Chemokines and their receptors not only affect the progression of HCC directly or indirectly, but also serve an important biological role in the migration of these cells, broadening the research field to include host and tumor interactions. For example, CCL15 recruits CCR $1^{+} \mathrm{CD} 14^{+}$ monocytes to the HCC invasive margin, and these monocytes in turn suppress the antitumor immune response, promote angiogenesis and accelerate HCC metastasis (135). Blockage of the CCL15-CCR1 axis decreases HCC growth and metastasis in vivo, representing a promising therapeutic approach (135). Based on the involvement of tumor-associated macrophages in cancer survival and proliferation, targeting the chemokines and their receptors may result in a valuable prognostic impact and may assist in the identification of novel immunity-based cancer treatments. It is hypothesized that patients with HCC may obtain more benefits when chemokines/receptors are regulated.

In addition, exosomes, which mediate the transport of various proteins, DNA and RNA molecules, may be used as drug carriers; exosomes expressing chemokines can more effectively induce chemotaxis to specific lesions (131-133). Thus, there is significant potential for exosomes modified by chemokines to deliver drugs directly, thus inhibiting the occurrence and development of $\mathrm{HCC}$, and this highlights the future direction for further research.

\section{Acknowledgements}

Not applicable.

\section{Funding}

The present review was supported by the Hebei Provincial Government Clinical Medicine Talents Training and Basic Research Project (grant no. 361003).

\section{Availability of data and materials}

Not applicable.

\section{Authors' contributions}

DX and YZ wrote and reviewed the manuscript. DX, YL and $\mathrm{JH}$ designed the figures. DX, JH and JW edited the manuscript. DX, YZ and JW assessed all the raw data. YP and HT critically revised the manuscript. YL, YP and HT are responsible 
for confirming the authenticity of the data. All authors read and approved the final version of the manuscript.

\section{Ethics approval and consent to participate}

Not applicable.

\section{Patient consent for publication}

Not applicable.

\section{Competing interests}

The authors declare that they have no competing interests.

\section{References}

1. Dong G, Zhang S, Shen S, Sun L, Wang X, Wang H, Wu J, Liu T, Wang C, Wang H, et al: SPATS2, negatively regulated by miR-145-5p, promotes hepatocellular carcinoma progression through regulating cell cycle. Cell Death Dis 11: 837, 2020.

2. Zhang FP, Huang YP, Luo WX, Deng WY, Liu CQ, Xu LB and Liu C: Construction of a risk score prognosis model based on hepatocellular carcinoma microenvironment. World J Gastroenterol 26: 134-153, 2020.

3. Zhang XF, Yang X, Jia HL, Zhu WW, Lu L, Shi W, Zhang H, Chen JH, Tao YF, Wang ZX, et al: Bcl-2 expression is a poor predictor for hepatocellular carcinoma prognosis of andropause-age patients. Cancer Biol Med 13: 459-468, 2016

4. Gnoni A, Santini D, Scartozzi M, Russo A, Licchetta A, Palmieri V, Lupo L, Faloppi L, Palasciano G, Memeo V, et al: Hepatocellular carcinoma treatment over sorafenib: Epigenetics, microRNAs and microenvironment. Is there a light at the end of the tunnel? Expert Opin Ther Targets 19: 1623-1635, 2015.

5. Paget S: The distribution of secondary growth in cancer. Lancet 1: 571-573, 1889.

6. Sainz B and Heeschen C: Standing out from the crowd: Cancer stem cells in hepatocellular carcinoma. Cancer Cell 23: 431-433, 2013.

7. Li J and Zhu Y: Recent advances in liver cancer stem cells: Non-coding RNAs, oncogenes and oncoproteins. Front Cell Dev Biol 8: 548335, 2020.

8. Kakinuma T and Hwang ST: Chemokines, chemokine receptors, and cancer metastasis. J Leukoc Biol 79: 639-651, 2006.

9. Nagarsheth N, Wicha MS and Zou W: Chemokines in the cancer microenvironment and their relevance in cancer immunotherapy. Nat Rev Immunol 17: 559-572, 2017.

10. Griffith JW, Sokol CL and Luster AD: Chemokines and chemokine receptors: Positioning cells for host defense and immunity. Annu Rev Immunol 32: 659-702, 2014.

11. Sakai N, Yoshidome H, Shida T, Kimura F, Shimizu H, Ohtsuka M, Takeuchi D, Sakakibara M and Miyazaki M: CXCR4/CXCL12 expression profile is associated with tumor microenvironment and clinical outcome of liver metastases of colorectal cancer. Clin Exp Metastasis 29: 101-110, 2012.

12. Rezaeeyan H, Shirzad R, McKee TD and Saki N: Role of chemokines in metastatic niche: New insights along with a diagnostic and prognostic approach. APMIS 126: 359-370, 2018.

13. Raffaella B and Graham GJ: Atypical chemokine receptors and their roles in the resolution of the inflammatory response. Front Immunol 7: 224, 2016.

14. Saaber F, Schütz D, Miess E, Abe P, Desikan S, Ashok Kumar P, Balk S, Huang K, Beaulieu JM, Schulz S and Stumm R: ACKR3 regulation of neuronal migration requires ACKR3 phosphorylation, but not $\beta$-Arrestin. Cell Rep 26: 1473-1488.e9, 2019.

15. Purvanov V, Matti C, Samson GPB, Kindinger I and Legler DF: Fluorescently tagged CCL19 and CCL21 to monitor CCR7 and ACKR4 functions. Int J Mol Sci 19: 3876, 2018.

16. Matti C, D'Uonnolo G, Artinger M, Melgrati S, Salnikov A, Thelen S, Purvanov V, Strobel TD, Spannagel L, Thelen M and Legler DF: CCL20 is a novel ligand for the scavenging atypical chemokine receptor 4. J Leukoc Biol 107: 1137-1154, 2020.

17. Do HTT, Lee CH and Cho J: Chemokines and their receptors: Multifaceted roles in cancer progression and potential value as cancer prognostic markers. Cancers (Basel) 12: 287, 2020.
18. Ozakyol A: Global epidemiology of hepatocellular carcinoma (HCC Epidemiology). J Gastrointest Cancer 48: 238-240, 2017.

19. Giannelli G, Rani B, Dituri F, Cao Y and Palasciano G: Moving towards personalised therapy in patients with hepatocellular carcinoma: The role of the microenvironment. Gut 63: 1668-1676, 2014.

20. Marra F and Tacke F: Roles for chemokines in liver disease. Gastroenterology 147: 577-594.e1, 2014.

21. Chiu DK, Xu IM, Lai RK, Tse AP, Wei LL, Koh HY, Li LL, Lee D, Lo RC, Wong CM, et al: Hypoxia induces myeloid-derived suppressor cell recruitment to hepatocellular carcinoma through chemokine (C-C motif) ligand 26. Hepatology 64: 797-813, 2016.

22. Kryczek I, Wang L, Wu K, Li W, Zhao E, Cui T, Wei S, Liu Y, Wang Y, Vatan L, et al: Inflammatory regulatory $\mathrm{T}$ cells in the microenvironments of ulcerative colitis and colon carcinoma. Oncoimmunology 5: e1105430, 2016.

23. Kryczek I, Wu K, Zhao E, Wei S, Vatan L, Szeliga W, Huang E, Greenson J, Chang A, Roliński J, et al: $\mathrm{IL}-17^{+}$regulatory T cells in the microenvironments of chronic inflammation and cancer. J Immunol 186: 4388-4395, 2011.

24. Han KQ, He XQ, Ma MY, Guo XD, Zhang XM, Chen J, Han H, Zhang WW, Zhu QG, Nian H and Ma LJ: Inflammatory microenvironment and expression of chemokines in hepatocellular carcinoma. World J Gastroenterol 21: 4864-4874, 2015.

25. Dagouassat M, Suffee N, Hlawaty H, Haddad O, Charni F, Laguillier C, Vassy R, Martin L, Schischmanoff PO, Gattegno L, et al: Monocyte chemoattractant protein-1 (MCP-1)/CCL2 secreted by hepatic myofibroblasts promotes migration and invasion of human hepatoma cells. Int J Cancer 126: 1095-1108, 2010.

26. Zhang H, He G, Kong Y, Chen Y, Wang B, Sun X, Jia B, Xie X, Wang X, Chen D, et al: Tumour-activated liver stromal cells regulate myeloid-derived suppressor cells accumulation in the liver. Clin Exp Immunol 188: 96-108, 2017.

27. Kee JY, Ito A, Hojo S, Hashimoto I, Igarashi Y, Tsukada K, Irimura T, Shibahara N, Nakayama T, Yoshie O, et al: Chemokine CXCL16 suppresses liver metastasis of colorectal cancer via augmentation of tumor-infiltrating natural killer $\mathrm{T}$ cells in a murine model. Oncol Rep 29: 975-982, 2013.

28. Kee JY, Ito A, Hojo S, Hashimoto I, Igarashi Y, Tsuneyama K, Tsukada K, Irimura T, Shibahara N, Takasaki I, et al: CXCL16 suppresses liver metastasis of colorectal cancer by promoting TNF- $\alpha$-induced apoptosis by tumor-associated macrophages. BMC Cancer 14: 949, 2014.

29. Adamski V, Hattermann K, Kubelt C, Cohrs G, Lucius R, Synowitz M, Sebens S and Held-Feindt J: Entry and exit of chemotherapeutically-promoted cellular dormancy in glioblastoma cells is differentially affected by the chemokines CXCL12, CXCL16, and CX3CL1. Oncogene 39: 4421-4435, 2020.

30. Takiguchi G, Nishita M, Kurita K, Kakeji Y and Minami Y: Wnt5a-Ror2 signaling in mesenchymal stem cells promotes proliferation of gastric cancer cells by activating CXCL16-CXCR6 axis. Cancer Sci 107: 290-297, 2016.

31. Shi JY, Yang LX, Wang ZC, Wang LY, Zhou J, Wang XY, Shi GM, Ding ZB, Ke AW, Dai Z, et al: CC chemokine receptor-like 1 functions as a tumour suppressor by impairing CCR7-related chemotaxis in hepatocellular carcinoma. J Pathol 235: 546-558, 2015.

32. Shi JY, Duan M, Sun QM, Yang L, Wang ZC, Mynbaev OA, He YF, Wang LY, Zhou J, Tang QQ, et al: Naive Treg-like CCR $7^{+}$ mononuclear cells indicate unfavorable prognosis in hepatocellular carcinoma. Tumour Biol 37: 9909-9917, 2016.

33. Wong HS, Jaumouillé V, Heit B, Doodnauth SA, Patel S, Huang YW, Grinstein S and Robinson LA: Cytoskeletal confinement of CX3CL1 limits its susceptibility to proteolytic cleavage by ADAM10. Mol Biol Cell 25: 3884-3899, 2014.

34. Sun C, Hu A, Wang S, Tian B, Jiang L, Liang Y, Wang H and Dong J: ADAM17-regulated CX3CL1 expression produced by bone marrow endothelial cells promotes spinal metastasis from hepatocellular carcinoma. Int J Oncol 57: 249-263, 2020.

35. Liu W, Jiang L, Bian C, Liang Y, Xing R, Yishakea M and Dong J: Role of CX3CL1 in diseases. Arch Immunol Ther Exp (Warsz) 64: 371-383, 2016.

36. Liu P, Liang Y, Jiang L, Wang $\mathrm{H}$, Wang $\mathrm{S}$ and Dong J: CX3CL1/fractalkine enhances prostate cancer spinal metastasis by activating the Src/FAK pathway. Int J Oncol 53: 1544-1556, 2018.

37. Liang Y, Yi L, Liu P, Jiang L, Wang H, Hu A, Sun C and Dong J: CX3CL1 involves in breast cancer metastasizing to the spine via the Src/FAK signaling pathway. J Cancer 9: 3603-3612, 2018 
38. Zheng J, Yang M, Shao J, Miao Y, Han J and Du J: Chemokine receptor CX3CR1 contributes to macrophage survival in tumor metastasis. Mol Cancer 12: 141, 2013.

39. Chen EB, Zhou ZJ, Xiao K, Zhu GQ, Yang Y, Wang B, Zhou SL, Chen Q, Yin D, Wang Z, et al: The miR-561-5p/CX ${ }_{3} \mathrm{CL} 1$ signaling axis regulates pulmonary metastasis in hepatocellular carcinoma involving $\mathrm{CX}_{3} \mathrm{CR}^{+}$natural killer cells infiltration. Theranostics 9: 4779-4794, 2019.

40. Miao S, Lu M, Liu Y, Shu D, Zhu Y, Song W, Ma Y, Ma R, Zhang B, Fang C and Ming ZY: Platelets are recruited to hepatocellular carcinoma tissues in a CX3CL1-CX3CR1 dependent manner and induce tumour cell apoptosis. Mol Oncol 14: 2546-2559, 2020.

41. Yoshida T, Imai T, Takagi S, Nishimura M, Ishikawa I, Yaoi T and Yoshie O: Structure and expression of two highly related genes encoding SCM-1/human lymphotactin. FEBS Lett 395 82-88, 1996.

42. Lei Y and Takahama Y: XCL1 and XCR1 in the immune system. Microbes Infect 14: 262-267, 2012.

43. Yamazaki C, Sugiyama M, Ohta T, Hemmi H, Hamada E, Sasaki I, Fukuda Y, Yano T, Nobuoka M, Hirashima T, et al: Critical roles of a dendritic cell subset expressing a chemokine receptor, XCR1. J Immunol 190: 6071-6082, 2013.

44. Khurram SA, Whawell SA, Bingle L, Murdoch C, McCabe BM and Farthing PM: Functional expression of the chemokine receptor XCR1 on oral epithelial cells. J Pathol 221: 153-163, 2010.

45. Gantsev SK, Umezawa K, Islamgulov DV, Khusnutdinova EK, Ishmuratova RS, Frolova VY and Kzyrgalin SR: The role of inflammatory chemokines in lymphoid neoorganogenesis in breast cancer. Biomed Pharmacother 67: 363-366, 2013.

46. Kim M, Rooper L, Xie J, Rayahin J, Burdette JE, Kajdacsy-Balla AA and Barbolina MV: The lymphotactin receptor is expressed in epithelial ovarian carcinoma and contributes to cell migration and proliferation. Mol Cancer Res 10: 1419-1429, 2012.

47. Wang T, Han S, Wu Z, Han Z, Yan W, Liu T, Wei H, Song D, Zhou W, Yang X and Xiao J: XCR1 promotes cell growth and migration and is correlated with bone metastasis in non-small cell lung cancer. Biochem Biophys Res Commun 464: 635-641, 2015.

48. Yanru W, Zhenyu B, Zhengchuan N, Qi Q, Chunmin L and Weiqiang Y: Transcriptomic analyses of chemokines reveal that down-regulation of XCR1 is associated with advanced hepatocellular carcinoma. Biochem Biophys Res Commun 496: 1314-1321, 2018.

49. Li X: The inducers of immunogenic cell death for tumor immunotherapy. Tumori 104: 1-8, 2018.

50. Mizumoto Y, Hemmi H, Katsuda M, Miyazawa M Kitahata Y, Miyamoto A, Nakamori M, Ojima T, Matsuda K, Nakamura M, et al: Anticancer effects of chemokine-directed antigen delivery to a cross-presenting dendritic cell subset with immune checkpoint blockade. Br J Cancer 122: 1185-1193, 2020.

51. Spranger $S$ and Gajewski TF: A new paradigm for tumor immune escape: $\beta$-catenin-driven immune exclusion. J Immunother Cancer 3: 43, 2015.

52. Botelho NK, Tschumi BO, Hubbell JA, Swartz MA, Donda A and Romero P: Combination of synthetic long peptides and XCL1 fusion proteins results in superior tumor control. Front Immunol 10: 294, 2019.

53. Chen K, Wu Z, Zhao H, Wang Y, Ge Y, Wang D, Li Z, An C, Liu Y, Wang F, et al: XCL1/Glypican-3 fusion gene immunization generates potent antitumor cellular immunity and enhances Anti-PD-1 efficacy. Cancer Immunol Res 8: 81-93, 2020.

54. Audsley KM, McDonnell AM and Waithman J: Cross-presenting $\mathrm{XCR} 1^{+}$dendritic cells as targets for cancer immunotherapy. Cells 9: 565, 2020

55. Wylie B, Read J, Buzzai AC, Wagner T, Troy N, Syn G, Stone SR, Foley B, Bosco A, Cruickshank MN, et al: CD8 ${ }^{+} X C R 1^{\text {ne }}$ dendritic cells express high levels of toll-like receptor 5 and a unique complement of endocytic receptors. Front Immunol 9: $2990,2019$.

56. Qin CJ, Zhao LH, Zhou X, Zhang HL, Wen W, Tang L, Zeng M, Wang MD, Fu GB, Huang S, et al: Inhibition of dipeptidyl peptidase IV prevents high fat diet-induced liver cancer angiogenesis by downregulating chemokine ligand 2. Cancer Lett 420: 26-37, 2018.

57. Giles AJ, Reid CM, Evans JD, Murgai M, Vicioso Y, Highfill SL, Kasai M, Vahdat L, Mackall CL, Lyden D, et al: Activation of hematopoietic stem/progenitor cells promotes immunosuppression within the pre-metastatic niche. Cancer Res 76: 1335-1347, 2016.
58. Chang AL, Miska J, Wainwright DA, Dey M, Rivetta CV, Yu D, Kanojia D, Pituch KC, Qiao J, Pytel P, et al: CCL2 produced by the glioma microenvironment is essential for the recruitment of regulatory $\mathrm{T}$ cells and myeloid-derived suppressor cells. Cancer Res 76: 5671-5682, 2016.

59. Qi S, Perrino S, Miao X, Lamarche-Vane N and Brodt P: The chemokine CCL7 regulates invadopodia maturation and MMP-9 mediated collagen degradation in liver-metastatic carcinoma cells. Cancer Lett 483: 98-113, 2020.

60. Wu Q, Chen JX, Chen Y, Cai LL, Wang XZ, Guo WH and Zheng JF: The chemokine receptor CCR10 promotes inflammation-driven hepatocarcinogenesis via PI3K/Akt pathway activation. Cell Death Dis 9: 232, 2018.

61. Hippe A, Braun SA, Oláh P, Gerber PA, Schorr A, Seeliger S, Holtz S, Jannasch K, Pivarcsi A, Buhren B, et al: EGFR/Ras-induced CCL20 production modulates the tumour microenvironment. Br J Cancer 123: 942-954, 2020.

62. Du D, Liu Y, Qian H, Zhang B, Tang X, Zhang T and Liu W: The effects of the CCR6/CCL20 biological axis on the invasion and metastasis of hepatocellular carcinoma. Int J Mol Sci 15: 6441-6452, 2014

63. Huang F and Geng XP: Chemokines and hepatocellular carcinoma. World J Gastroenterol 16: 1832-1836, 2010.

64. Tan H, Wang S and Zhao L: A tumour-promoting role of Th9 cells in hepatocellular carcinoma through CCL20 and STAT3 pathways. Clin Exp Pharmacol Physiol 44: 213-221, 2017.

65. Facciabene A, Peng X, Hagemann IS, Balint K, Barchetti A, Wang LP, Gimotty PA, Gilks CB, Lal P, Zhang L and Coukos G: Tumour hypoxia promotes tolerance and angiogenesis via CCL28 and T(reg) cells. Nature 475: 226-230, 2011

66. Gao Y, Zhou Z, Lu S, Huang X, Zhang C, Jiang R, Yao A, Sun B and Wang X: Chemokine CCL15 mediates migration of human bone marrow-derived mesenchymal stem cells toward hepatocellular carcinoma. Stem Cells 34: 1112-1122, 2016.

67. Singh SK, Mishra MK, Eltoum IA, Bae S, Lillard JW Jr and Singh R: CCR5/CCL5 axis interaction promotes migratory and invasiveness of pancreatic cancer cells. Sci Rep 8: 1323, 2018.

68. Singh SK, Mishra MK, Rivers BM, Gordetsky JB, Bae S and Singh R: Biological and clinical significance of the CCR5/CCL5 axis in hepatocellular carcinoma. Cancers (Basel) 12: 883, 2020.

69. Sasaki R, Devhare PB, Steele R, Ray R and Ray RB: Hepatitis $\mathrm{C}$ virus-induced CCL5 secretion from macrophages activates hepatic stellate cells. Hepatology 66: 746-757, 2017.

70. González-Martín A, Mira E and Mañes S: CCR5 in cancer immunotherapy: More than an 'attractive' receptor for T cells. Oncoimmunology 1: 106-108, 2012.

71. Wang T, Zhan Q, Peng X, Qiu Z and Zhao T: CCL2 influences the sensitivity of lung cancer A549 cells to docetaxel. Oncol Lett 16: 1267-1274, 2018.

72. Pasquier J, Gosset M, Geyl C, Hoarau-Véchot J, Chevrot A, Pocard M, Mirshahi M, Lis R, Rafii A and Touboul C: CCL2/CCL5 secreted by the stroma induce IL-6/PYK2 dependent chemoresistance in ovarian cancer. Mol Cancer 17: 47, 2018.

73. Su S, Sun X, Zhang Q, Zhang Z and Chen J: CCL20 promotes ovarian cancer chemotherapy resistance by regulating ABCB1 expression. Cell Struct Funct 44: 21-28, 2019.

74. Vaquero J, Briz O, Herraez E, Muntané J and Marin JJ: Activation of the nuclear receptor FXR enhances hepatocyte chemoprotection and liver tumor chemoresistance against genotoxic compounds. Biochim Biophys Acta 1833: 2212-2219, 2013.

75. Gu Y, Li X, Bi Y, Zheng Y, Wang J, Li X, Huang Z, Chen L, Huang Y and Huang Y: CCL14 is a prognostic biomarker and correlates with immune infiltrates in hepatocellular carcinoma. Aging (Albany NY) 12: 784-807, 2020.

76. Rodríguez-Perea AL, Rojas M and Velilla-Hernández PA: High concentrations of atorvastatin reduce in-vitro function of conventional T and regulatory T cells. Clin Exp Immunol 196: 237-248, 2019.

77. Zhu M, Xu W, Wei C, Huang J, Xu J, Zhang Y, Zhao Y, Chen J, Dong S, Liu B and Liang C: CCL14 serves as a novel prognostic factor and tumor suppressor of HCC by modulating cell cycle and promoting apoptosis. Cell Death Dis 10: 796, 2019.

78. Zhang X, Wan JX, Ke ZP, Wang F, Chai HX and Liu JQ: TMEM88, CCL14 and CLEC3B as prognostic biomarkers for prognosis and palindromia of human hepatocellular carcinoma. Tumour Biol 39: 1010428317708900, 2017.

79. Wilson GC, Kuboki S, Freeman CM, Nojima H, Schuster RM, Edwards MJ and Lentsch AB: CXC chemokines function as a rheostat for hepatocyte proliferation and liver regeneration. PLoS One 10: $\mathrm{e} 0120092,2015$. 
80. Vandercappellen J, Van Damme J and Struyf S: The role of CXC chemokines and their receptors in cancer. Cancer Lett 267: 226-244, 2008

81. Liu G, Yang ZF, Zhou PY, Zhou C, Guan RY, Sun BY, Fan J, Zhou J, Yi Y and Qiu SJ: ROR- $\alpha-1$ inhibits the proliferation, invasion, and migration of hepatocellular carcinoma $\mathrm{MHCC} 97 \mathrm{H}$ via downregulation of chemokine CXCL5. Cytokine 129: $155004,2020$.

82. Zhou SL, Zhou ZJ, Hu ZQ, Li X, Huang XW, Wang Z, Fan J, Dai $Z$ and Zhou J: CXCR2/CXCL5 axis contributes to epithelial-mesenchymal transition of HCC cells through activating PI3K/Akt/GSK-3 $3 /$ Snail signaling. Cancer Lettr 358: 124-135, 2015.

83. Li XP, Yang XY, Biskup E, Zhou J, Li HL, Wu YF, Chen ML and Xu F: Co-expression of CXCL8 and HIF-1 $\alpha$ is associated with metastasis and poor prognosis in hepatocellular carcinoma. Oncotarget 6: 22880-22889, 2015.

84. Yamamoto M, Kikuchi H, Ohta M, Kawabata T, Hiramatsu Y, Kondo K, Baba M, Kamiya K, Tanaka T, Kitagawa M and Konno H: TSU68 prevents liver metastasis of colon cancer xenografts by modulating the premetastatic niche. Cancer Res 68 9754-9762, 2008.

85. Van den Eynden GG, Majeed AW, Illemann M, Vermeulen PB, Bird NC, Høyer-Hansen G, Eefsen RL, Reynolds AR and Brodt P The multifaceted role of the microenvironment in liver metastasis: Biology and clinical implications. Cancer Res 73: 2031-2043, 2013

86. Li L, Zhu YH, Li Y and Guan XY: Identification of chemokine CXCL10 in tumor microenvironment by antibody array as a prognostic marker in hepatocellular carcinoma. Neoplasma 64 778-786, 2017.

87. Li B, Su H, Cao J and Zhang L: CXCL13 rather than IL-31 is a potential indicator in patients with hepatocellular carcinoma. Cytokine 89: 91-97, 2017.

88. Song X, Wang Z, Jin Y, Wang Y and Duan W: Loss of miR-532-5p in vitro promotes cell proliferation and metastasis by influencing CXCL2 expression in HCC. Am J Transl Res 7: 2254-2261, 2015.

89. Ding J, Xu K, Zhang J, Lin B, Wang Y, Yin S, Xie H, Zhou L and Zheng S: Overexpression of CXCL2 inhibits cell proliferation and promotes apoptosis in hepatocellular carcinoma. BMB Rep 51: 630-635, 2018.

90. Subat S, Mogushi K, Yasen M, Kohda T, Ishikawa Y and Tanaka $\mathrm{H}$ : Identification of genes and pathways, including the CXCL2 axis, altered by DNA methylation in hepatocellular carcinoma. J Cancer Res Clin Oncol 145: 675-684, 2019.

91. Shi A, Shi H, Dong L, Xu S, Jia M, Guo X and Wang T: CXCR7 as a chemokine receptor for SDF-1 promotes gastric cancer progression via MAPK pathways. Scand J Gastroenterol 52: 745-753, 2017

92. Li D, Qu C, Ning Z, Wang H, Zang K, Zhuang L, Chen L, Wang P and Meng Z: Radiation promotes epithelial-to-mesenchymal transition and invasion of pancreatic cancer cell by activating carcinoma-associated fibroblasts. Am J Cancer Res 6: 2192-2206, 2016.

93. Croker AK and Allan AL: Cancer stem cells: Implications for the progression and treatment of metastatic disease. J Cell Mol Med 12: 374-390, 2008

94. Jahanban-Esfahlan R, de la Guardia M, Ahmadi D and Yousefi B Modulating tumor hypoxia by nanomedicine for effective cancer therapy. J Cell Physiol 233: 2019-2031, 2018.

95. Teng F, Tian WY, Wang YM, Zhang YF, Guo F, Zhao J, Gao C and Xue FX: Cancer-associated fibroblasts promote the progression of endometrial cancer via the SDF-1/CXCR4 axis. J Hematol Oncol 9: 8, 2016

96. Wang C, Wang MD, Cheng P, Huang H, Dong W, Zhang WW, Li PP, Lin C, Pan ZY, Wu MC and Zhou WP: Hepatitis B virus X protein promotes the stem-like properties of $\mathrm{OV}^{+}$cancer cells in hepatocellular carcinoma. Cell Death Dis 8: e2560, 2017.

97. Kaemmerer D, Schindler R, Mußbach F, Dahmen U, Altendorf-Hofmann A, Dirsch O, Sänger J, Schulz S and Lupp A: Somatostatin and CXCR4 chemokine receptor expression in hepatocellular and cholangiocellular carcinomas: Tumor capillaries as promising targets. BMC Cancer 17: 896, 2017.

98. Li H, Yang W, Chen PW, Alizadeh H and Niederkorn JY: Inhibition of chemokine receptor expression on uveal melanomas by CXCR4 siRNA and its effect on uveal melanoma liver metastases. Invest Ophthalmol Vis Sci 50: 5522-5528, 2009

99. Deol A, Abrams J, Masood A, Al-Kadhimi Z, Abidi MH, Ayash L, Lum LG, Ratanatharathorn V and Uberti JP: Long-term follow up of patients proceeding to transplant using plerixafor mobilized stem cells and incidence of secondary myelodysplastic syndrome/AML. Bone Marrow Transplant 48: 1112-1116, 2013.
100. Collins PJ, McCully ML, Martínez-Muñoz L, Santiago C, Wheeldon J, Caucheteux S, Thelen S, Cecchinato V, Laufer JM, Purvanov V, et al: Epithelial chemokine CXCL14 synergizes with CXCL12 via allosteric modulation of CXCR4. FASEB J 31 3084-3097, 2017.

101. Chen Y, Teng F, Wang G and Nie Z: Overexpression of CXCR7 induces angiogenic capacity of human hepatocellular carcinoma cells via the AKT signaling pathway. Oncol Rep 36: 2275-2281, 2016.

102. Lin L, Han MM, Wang F, Xu LL, Yu HX and Yang PY: CXCR7 stimulates MAPK signaling to regulate hepatocellular carcinoma progression. Cell Death Dis 5: e1488, 2014.

103. Billottet C, Quemener C and Bikfalvi A: CXCR3, a double-edged sword in tumor progression and angiogenesis. Biochim Biophys Acta 1836: 287-295, 2013.

104. Ma B, Khazali A and Wells A: CXCR3 in carcinoma progression. Histol Histopathol 30: 781-792, 2015.

105. Gao Q, Zhao YJ, Wang XY, Qiu SJ, Shi YH, Sun J, Yi Y, Shi JY, Shi GM, Ding ZB, et al: CXCR6 upregulation contributes to a proinflammatory tumor microenvironment that drives metastasis and poor patient outcomes in hepatocellular carcinoma. Cancer Res 72: 3546-3556, 2012.

106. Wu Y, Tian L, Xu Y, Zhang M, Xiang S, Zhao J and Wang Z: CXCR7 silencing inhibits the migration and invasion of human tumor endothelial cells derived from hepatocellular carcinoma by suppressing STAT3. Mol Med Rep 18: 1644-1650, 2018.

107. Xu Y, Fang F, Jiao H, Zheng X, Huang L, Yi X and Zhao W: Activated hepatic stellate cells regulate MDSC migration through the SDF-1/CXCR4 axis in an orthotopic mouse mode of hepatocellular carcinoma. Cancer Immunol Immunother 68: 1959-1969, 2019.

108. Tian H, Huang P, Zhao Z, Tang W and Xia J: HIF-1 $\alpha$ plays a role in the chemotactic migration of hepatocarcinoma cells through the modulation of CXCL6 expression. Cell Physiol Biochem 34: 1536-1546, 2014.

109. Shen H, Yao X, Li H, Li X, Zhang T, Sun Q, Ji C and Chen G: Role of exosomes derived from miR-133b modified MSCs in an experimental rat model of intracerebral hemorrhage. J Mol Neurosci 64: 421-430, 2018.

110. Halvaei S, Daryani S, Eslami-S Z, Samadi T, Jafarbeik-Iravani N Bakhshayesh TO, Majidzadeh-A K and Esmaeili R: Exosomes in cancer liquid biopsy: A focus on breast cancer. Mol Ther Nucleic Acids 10: 131-141, 2018.

111. Anel A, Gallego-Lleyda A, de Miguel D, Naval J and Martínez-Lostao L: Role of exosomes in the regulation of T-cell mediated immune responses and in autoimmune disease. Cells 8: 154, 2019.

112. Almeida VH, Rondon AMR, Gomes T and Monteiro RQ: Novel aspects of extracellular vesicles as mediators of cancer-associated thrombosis. Cells 8: 716, 2019.

113. Rao PSS, O'Connell K and Finnerty TK: Potential role of extracellular vesicles in the pathophysiology of drug addiction. Mol Neurobiol 55: 6906-6913, 2018.

114. Kohama I, Kosaka N, Chikuda H and Ochiya T: An insight into the roles of MicroRNAs and exosomes in sarcoma. Cancers (Basel) 11: 428, 2019

115. Mashouri L, Yousefi H, Aref AR, Ahadi AM, Molaei F and Alahari SK: Exosomes: Composition, biogenesis, and mechanisms in cancer metastasis and drug resistance. Mol Cancer 18: 75, 2019.

116. Sun JF, Zhang D, Gao CJ, Zhang YW and Dai QS Exosome-mediated MiR-155 transfer contributes to hepatocellular carcinoma cell proliferation by targeting PTEN. Med Sci Monit Basic Res 25: 218-228, 2019.

117. Lee JY and Kim HS: Extracellular vesicles in neurodegenerative diseases: A double-edged sword. Tissue Eng Regen Med 14 667-678, 2017.

118. Johnsen KB, Gudbergsson JM, Skov MN, Pilgaard L, Moos T and Duroux M: A comprehensive overview of exosomes as drug delivery vehicles-endogenous nanocarriers for targeted cancer therapy. Biochim Biophys Acta 1846: 75-87, 2014

119. Yi YW, Lee JH, Kim SY, Pack CG, Ha DH, Park SR, Youn J and Cho BS: Advances in analysis of biodistribution of exosomes by molecular imaging. Int J Mol Sci 21: 665, 2020.

120. Wu P, Zhang B, Ocansey DKW, Xu W and Qian H: Extracellular vesicles: A bright star of nanomedicine. Biomaterials 6: 120467 , 2020.

121. Kim MS, Haney MJ, Zhao Y, Mahajan V, Deygen I, Klyachko NL, Inskoe E, Piroyan A, Sokolsky M, Okolie O, et al: Development of exosome-encapsulated paclitaxel to overcome MDR in cancer cells. Nanomedicine 12: 655-664, 2016 
122. Si Y, Kim S, Zhang E, Tang Y, Jaskula-Sztul R, Markert JM, Chen H, Zhou L and Liu XM: Targeted exosomes for drug delivery: Biomanufacturing, surface tagging, and validation. Biotechnol J 15: e1900163, 2020.

123. Prada I and Meldolesi J: Binding and fusion of extracellular vesicles to the plasma membrane of their cell targets. Int $\mathbf{J}$ Mol Sci 17: 1296, 2016.

124. Nakase I and Futaki S: Combined treatment with a $\mathrm{pH}$-sensitive fusogenic peptide and cationic lipids achieves enhanced cytosolic delivery of exosomes. Sci Rep 5: 10112, 2015.

125. Kooijmans SA, Aleza CG, Roffler SR, van Solinge WW, Vader P and Schiffelers RM: Display of GPI-anchored anti-EGFR nanobodies on extracellular vesicles promotes tumour cell targeting. J Extracell Vesicles 5: 31053, 2016.

126. Hashimoto K, Ochi H, Sunamura S, Kosaka N, Mabuchi Y, Fukuda T, Yao K, KandaH,Ae K, Okawa A, et al: Cancer-secreted hsa-miR-940 induces an osteoblastic phenotype in the bone metastatic microenvironment via targeting ARHGAP1 and FAM134A. Proc Natl Acad Sci USA 115: 2204-2209, 2018.

127. Luis-Ravelo D, Antón I, Zandueta C, Valencia K, Ormazábal C, Martínez-Canarias S, Guruceaga E, Perurena N, Vicent S, De Las Rivas J and Lecanda F: A gene signature of bone metastatic colonization sensitizes for tumor-induced osteolysis and predicts survival in lung cancer. Oncogene 33: 5090-5099, 2014

128. Hoshino A, Costa-Silva B, Shen TL, Rodrigues G, Hashimoto A, Tesic Mark M, Molina H, Kohsaka S, Di Giannatale A, Ceder S, et al: Tumour exosome integrins determine organotropic metastasis. Nature 527: 329-335, 2015.

129. Li H, Yang C, Shi Y and Zhao L: Exosomes derived from siRNA against GRP78 modified bone-marrow-derived mesenchymal stem cells suppress Sorafenib resistance in hepatocellular carcinoma. J Nanobiotechnology 16: 103, 2018.

130. Viñas JL, Spence M, Gutsol A, Knoll W, BurgerD,Zimpelmann J, Allan DS and Burns KD: Receptor-ligand interaction mediates targeting of endothelial colony forming cell-derived exosomes to the kidney after ischemic injury. Sci Rep 8: 16320, 2018.

131. Ciullo A, Biemmi V, Milano G, Bolis S, Cervio E, Fertig ET, Gherghiceanu M, Moccetti T, Camici GG, Vassalli G and Barile L: Exosomal expression of CXCR4 targets cardioprotective vesicles to myocardial infarction and improves outcome after systemic administration. Int J Mol Sci 20: 468, 2019.

132. Wei G, Jie Y, Haibo L, Chaoneng W, Dong H, Jianbing Z, Junjie G, Leilei M, Hongtao S, Yunzeng Z and Junbo G: Dendritic cells derived exosomes migration to spleen and induction of inflammation are regulated by CCR7. Sci Rep 7: 42996, 2017.

133. Longo V, Gnoni A, Casadei Gardini A, Pisconti S, Licchetta A Scartozzi M, Memeo R, Palmieri VO, Aprile G, Santini D, et al Immunotherapeutic approaches for hepatocellular carcinoma. Oncotarget 8: 33897-33910, 2017.

134. Liu YC, Yeh CT and Lin KH: Cancer stem cell functions in hepatocellular carcinoma and comprehensive therapeutic strategies. Cells 9: 1331, 2020

135. Liu LZ, Zhang Z, Zheng BH, Shi Y, Duan M, Ma LJ, Wang ZC, Dong LQ, Dong PP, Shi JY, et al: CCL15 recruits suppressive monocytes to facilitate Immune escape and disease progression in hepatocellular carcinoma. Hepatology 69: 143-159, 2019.

136. Sun F, Wang J, Sun Q, Li F, Gao H, Xu L, Zhang J, Sun X, Tian Y, Zhao $\mathrm{Q}$, et al: Interleukin-8 promotes integrin $\beta 3$ upregulation and cell invasion through PI3K/Akt pathway in hepatocellular carcinoma. J Exp Clin Cancer Res 38: 449, 2019.

137. Li L, Xu L, Yan J, Zhen ZJ, Ji Y, Liu CQ, Lau WY, Zheng L and $\mathrm{Xu}$ J: CXCR2-CXCL1 axis is correlated with neutrophil infiltration and predicts a poor prognosis in hepatocellular carcinoma. J Exp Clin Cancer Res 34: 129, 2015

138. Lu Y, Li S, Ma L, Li Y, Zhang X, Peng Q, Mo C, Huang L, Qin X and Liu Y: Type conversion of secretomes in a 3D TAM2 and HCC cell co-culture system and functional importance of CXCL2 in HCC. Sci Rep 6: 24558, 2016.

139. Zhang L, Zhang L, Li H, Ge C, Zhao F, Tian H, Chen T, Jiang G, $\mathrm{Xie} \mathrm{H}$, Cui Y, et al: CXCL3 contributes to CD133 ${ }^{+} \mathrm{CSC}$ maintenance and forms a positive feedback regulation loop with CD133 in HCC via Erk1/2 phosphorylation. Sci Rep 6: 27426, 2016.

140.Zhou SL, Dai Z, Zhou ZJ, Wang XY, Yang GH, Wang Z, Huang XW, Fan J and Zhou J: Overexpression of CXCL5 mediates neutrophil infiltration and indicates poor prognosis for hepatocellular carcinoma. Hepatology 56: 2242-2254, 2012.

141. Ding Q, Xia Y, Ding S, Lu P, Sun L and Liu M: An alternatively spliced variant of CXCR3 mediates the metastasis of CD133+ liver cancer cells induced by CXCL9. Oncotarget 7: 14405-14414, 2016.
142. Ouyang Y,Liu K, Hao M, Zheng R, Zhang C, Wu Y,Zhang X,Li N, Zheng J and Chen D: Radiofrequency ablation-increased CXCL10 is associated with earlier recurrence of hepatocellular carcinoma by promoting stemness. Tumour Biol 37: 3697-3704, 2016.

143. Ling CC, Ng KT, Shao Y, Geng W, Xiao JW, Liu H, Li CX, Liu XB, Ma YY, Yeung WH, et al: Post-transplant endothelial progenitor cell mobilization via CXCL10/CXCR3 signaling promotes liver tumor growth. J Hepatol 60: 103-109, 2014.

144. Zhang Y, Zhao W, Li S, Lv M, Yang X, Li M and Zhang Z: CXCL11 promotes self-renewal and tumorigenicity of $\alpha 2 \delta 1^{+}$ liver tumor-initiating cells through CXCR3/ERK1/2 signaling. Cancer Lett 449: 163-171, 2019.

145. Li C, Kang D, Sun X, Liu Y, Wang J and Gao P: The effect of C-X-C motif chemokine 13 on hepatocellular carcinoma associates with Wnt signaling. Biomed Res Int 2015: 345413, 2015

146. Deng L, Chen N, Li Y, Zheng H and Lei Q: CXCR6/CXCL16 functions as a regulator in metastasis and progression of cancer. Biochim Biophys Acta 1806: 42-49, 2010.

147. Yuan Y, Liu J, Liu Z, He Y, Zhang Z, Jiang C and Qian Q: Chemokine CCL3 facilitates the migration of hepatoma cells by changing the concentration intracellular $\mathrm{Ca}$. Hepatol Res 40 : 424-431, 2010

148. Bai H, Weng Y, Bai S, Jiang Y, Li B, He F, Zhang R, Yan S, Deng F, Wang J and Shi Q: CCL5 secreted from bone marrow stromal cells stimulates the migration and invasion of Huh7 hepatocellular carcinoma cells via the PI3K-Akt pathway. Int J Oncol 45: 333-343, 2014

149. Liao WC, Yen HR, Liao CK, Tseng TJ, Lan CT and Liu CH: DSE regulates the malignant characters of hepatocellular carcinoma cells by modulating CCL5/CCR 1 axis. Am J Cancer Res 9: 347-362, 2019.

150. Li Y, Wu J and Zhang P: CCL15/CCR1 axis is involved in hepatocellular carcinoma cells migration and invasion. Tumour Biol 37: 4501-4507, 2016

151. Lu J, Yang Y, Yu P, Tao H, Lu X, Wang L, Liu D, Chen Y and Chen $\mathrm{C}$ : Bioinformatics analysis and significance of expression of CC chemokine ligand 23 (CCL23) in hepatocellular carcinoma. Xi Bao Yu Fen Zi Mian Yi Xue Za Zhi 35: 903-909, 2019 (In Chinese).

152. Zhuang H, Cao G, Kou C and Liu T: CCL2/CCR2 axis induces hepatocellular carcinoma invasion and epithelial-mesenchymal transition in vitro through activation of the Hedgehog pathway. Oncol Rep 39: 21-30, 2018

153. Jin L, Liu WR, Tian MX, Jiang XF, Wang H, Zhou PY, Ding ZB, Peng YF, Dai Z, Qiu SJ, et al: CCL24 contributes to HCC malignancy via RhoB-VEGFA-VEGFR2 angiogenesis pathway and indicates poor prognosis. Oncotarget 8: 5135-5148, 2017.

154. Zhu F, Li X, Chen S, Zeng Q, Zhao Y and Luo F: Tumor-associated macrophage or chemokine ligand CCL17 positively regulates the tumorigenesis of hepatocellular carcinoma. Med Oncol 33: 17,2016

155. Wiedemann GM, Röhrle N, Makeschin MC, Fesseler J, Endres S, Mayr D and Anz D: Peritumoural CCL1 and CCL22 expressing cells in hepatocellular carcinomas shape the tumour immune infiltrate. Pathology 51: 586-592, 2019.

156. Cheng X, Wu H, Jin ZJ, Ma D, Yuen S, Jing XQ, Shi MM, Shen BY, Peng $\mathrm{CH}$, Zhao R and Qiu WH: Up-regulation of chemokine receptor CCR4 is associated with Human Hepatocellular Carcinoma malignant behavior. Sci Rep 7: $12362,2017$.

157. Mukaida N, Sasaki SI and Baba T: CCL4 signaling in the tumor microenvironment. Adv Exp Med Biol 1231: 23-32, 2020.

158. Luo KQ, Shi YN and Peng JC: The effect of chemokine CC motif ligand 19 on the proliferation and migration of hepatocellular carcinoma. Tumour Biol 35: 12575-12581, 2014

159. Yang L, Chang Y and Cao P: CCR7 preservation via histone deacetylase inhibition promotes epithelial-mesenchymal transition of hepatocellular carcinoma cells. Exp Cell Res 371: 231-237, 2018.

160. Hou PP, Luo LJ, Chen HZ, Chen QT, Bian XL, Wu SF, Zhou JX, Zhao WX, Liu JM, Wang XM, et al: Ectosomal PKM2 promotes $\mathrm{HCC}$ by inducing macrophage differentiation and remodeling the tumor microenvironment. Mol Cell 78: 1192-1206.e10, 2020.

161. Xu B, Deng C, Wu X, Ji T, Zhao L, Han Y, Yang W, Qi Y, Wang Z, Yang Z and Yang Y: CCR9 and CCL25: A review of their roles in tumor promotion. J Cell Physiol 235: 9121-9132, 2020.

This work is licensed under a Creative Commons Attribution-NonCommercial-NoDerivatives 4.0 International (CC BY-NC-ND 4.0) License. 